Review

\title{
Influence of Reduction Promoters on Stability of Cobalt/ $\gamma$-Alumina Fischer-Tropsch Synthesis Catalysts
}

\author{
Gary Jacobs, Wenping Ma and Burtron H. Davis * \\ Center for Applied Energy Research, 2540 Research Park Drive, Lexington, KY 40511, USA; \\ E-Mails: gary.jacobs@uky.edu (G.J.); wenping.ma@uky.edu (W.M.) \\ * Author to whom correspondence should be addressed; E-Mail: burtron.davis@uky.edu; \\ Tel.: +1-859-257-0251; Fax: +1-859-257-0302.
}

Received: 31 October 2013; in revised form: 13 January 2014 / Accepted: 20 February 2014 /

Published: 11 March 2014

\begin{abstract}
This focused review article underscores how metal reduction promoters can impact deactivation phenomena associated with cobalt Fischer-Tropsch synthesis catalysts. Promoters can exacerbate sintering if the additional cobalt metal clusters, formed as a result of the promoting effect, are in close proximity at the nanoscale to other cobalt particles on the surface. Recent efforts have shown that when promoters are used to facilitate the reduction of small crystallites with the aim of increasing surface $\mathrm{Co}^{0}$ site densities (e.g., in research catalysts), ultra-small crystallites (e.g., $<2-4.4 \mathrm{~nm}$ ) formed are more susceptible to oxidation at high conversion relative to larger ones. The choice of promoter is important, as certain metals (e.g., Au) that promote cobalt oxide reduction can separate from cobalt during oxidation-reduction (regeneration) cycles. Finally, some elements have been identified to promote reduction but either poison the surface of $\mathrm{Co}^{0}$ (e.g., $\mathrm{Cu}$ ), or produce excessive light gas selectivity (e.g., $\mathrm{Cu}$ and $\mathrm{Pd}$, or $\mathrm{Au}$ at high loading). Computational studies indicate that certain promoters may inhibit polymeric $\mathrm{C}$ formation by hindering C-C coupling.
\end{abstract}

Keywords: Fischer-Tropsch synthesis; cobalt; deactivation; promoters

\section{Introduction}

Fischer-Tropsch synthesis (FTS) making use of cobalt catalysts is the core of the gas-to-liquids (GTL) process $[1,2]$. Due to the high $\mathrm{H}_{2} / \mathrm{CO}$ syngas ratio derived from reforming of natural gas, 
additional water gas shift is not required to adjust the ratio upward, and internal water-gas shift (WGS) activity is undesirable. This is one benefit of cobalt catalysts relative to iron catalysts for GTL, as the former typically possess low intrinsic WGS activity. Because cobalt is much more expensive than its iron counterpart, and because the reaction occurs on the surface, it is important to disperse the cobalt metal particles in order to improve usage efficiency.

A typical cost effective way to do so is to impregnate the pre-calcined support with a cobalt nitrate solution by wet or dry (incipient wetness) impregnation followed by drying, air calcination to decompose the cobalt nitrate precursor to cobalt oxide, and reduction (e.g., $10 \mathrm{~h}$ in hydrogen gas at $350{ }^{\circ} \mathrm{C}$ ) to $\mathrm{Co}^{0}$ crystallites (typically in the range of 5 to $20 \mathrm{~nm}$ ). The surface of Co particles provides the catalytically active sites for Fischer-Tropsch synthesis.

However, with typical reduction of supported cobalt at low temperatures (e.g., 350-400 ${ }^{\circ} \mathrm{C}$ ) appropriate for obtaining active small crystallites of 6-15 nm, a sizeable fraction (typically in the range of $15-70 \%$ ) of the cobalt remains in the oxide form, mainly as $\mathrm{CoO}$. The fraction of unreduced cobalt is larger for supports such as alumina which interact strongly with cobalt oxide and for low cobalt loadings, e.g., less than $10-15 \%$ on such supports. The extent of the interaction increases with decreasing loading of cobalt. At low loadings (e.g., $<5 \%$ ), 60 to $80 \%$ of the cobalt is present as $\mathrm{CoO}$ strongly bound to the support surface, i.e., a surface cobalt aluminate, $\mathrm{CoO}^{*} \mathrm{Al}_{2} \mathrm{O}_{3}$, which requires very high temperatures to reduce [3]. At high loadings (e.g., 15\%-30\% Co), cobalt will be present primarily as $\mathrm{Co}_{3} \mathrm{O}_{4}$, which reduces in two steps: $\mathrm{Co}_{3} \mathrm{O}_{4}+\mathrm{H}_{2}=3 \mathrm{CoO}+\mathrm{H}_{2} \mathrm{O}$ and $3 \mathrm{CoO}+3 \mathrm{CoO}=\mathrm{Co}+3 \mathrm{H}_{2} \mathrm{O}$, for which maximum rates of reduction occur at about $300-350$ and $500-650{ }^{\circ} \mathrm{C}$, respectively [4]. Thus, following reduction of an unpromoted $15-30 \% \mathrm{Co}$ /alumina at $350-400{ }^{\circ} \mathrm{C}$ for $5-15 \mathrm{~h}$, a significant fraction (30-60\%) of $\mathrm{CoO}$ typically remains [5-8]. Since higher extents of reduction (80-90\%) of cobalt are highly desirable, i.e., correlated with higher activity on a per $g$ catalyst basis, as well as improved $\mathrm{C}_{5}+$ selectivity, there is considerable interest and widespread application of noble metal promoters, which facilitate the reduction of cobalt oxides and increase the surface density of cobalt active sites.

This article reviews a number of stability issues associated with the application of promoters for cobalt FTS catalysts. Examples are provided to demonstrate a number of considerations for selecting a noble metal for Co catalysts. The main point of the article is that each promoter has its own advantages and set of issues that must be addressed and, in some cases, still defined.

\section{Results and Discussion}

Figure 1 compares temperature programmed reduction (TPR) TPR profiles of a number of noble metal and Group IB-promoted $15 \% \mathrm{Co} / \gamma-\mathrm{Al}_{2} \mathrm{O}_{3}$ catalysts pertinent to this review. The commonly used promoters are $\mathrm{Pt}, \mathrm{Re}$, and $\mathrm{Ru}$ and the solid line profiles are at close to atomically equivalent loadings. $\mathrm{Pt}$ and $\mathrm{Ru}$ facilitate the reduction of both steps of cobalt oxide reduction, while Re catalyzes the reduction of primarily the second step. This has been explained by Re oxide reducing at a higher temperature than $\mathrm{Pt}$ and $\mathrm{Ru}$ and that a reduced form of the promoter is required to obtain the promoting effect [7]; however, further confirmation of this is needed as the oxidation state remains in question [9]. Both $\mathrm{Pt}$ and $\mathrm{Re}$ appear to be more effective at facilitating reduction relative to $\mathrm{Ru}$, but higher loadings of $\mathrm{Ru}$ can be used to further facilitate reduction, as indicated by the dashed profile at $0.5 \% \mathrm{Ru}$ loading. 
Similar trends were reported in the TPR peak locations in a recent investigation of promoter characteristics by Cook et al. [9], as shown in Figure 2.

Figure 1. TPR profiles demonstrate the effectiveness of $\mathrm{Cu}$ for facilitating reduction of cobalt oxides. Curve labels: unpromoted $15 \% \mathrm{Co} / \mathrm{Al}_{2} \mathrm{O}_{3}$ (thick solid) and $\mathrm{Cu}$-promoted with $0.033 \% \mathrm{Cu}$ (thick dashed), $0.49 \% \mathrm{Cu}$ (thin solid), and $1.63 \% \mathrm{Cu}$ (thin dash-dotted) by weight. (Reproduced with permission from [7] and [10] Copyright 2002, 2009, Elsevier).

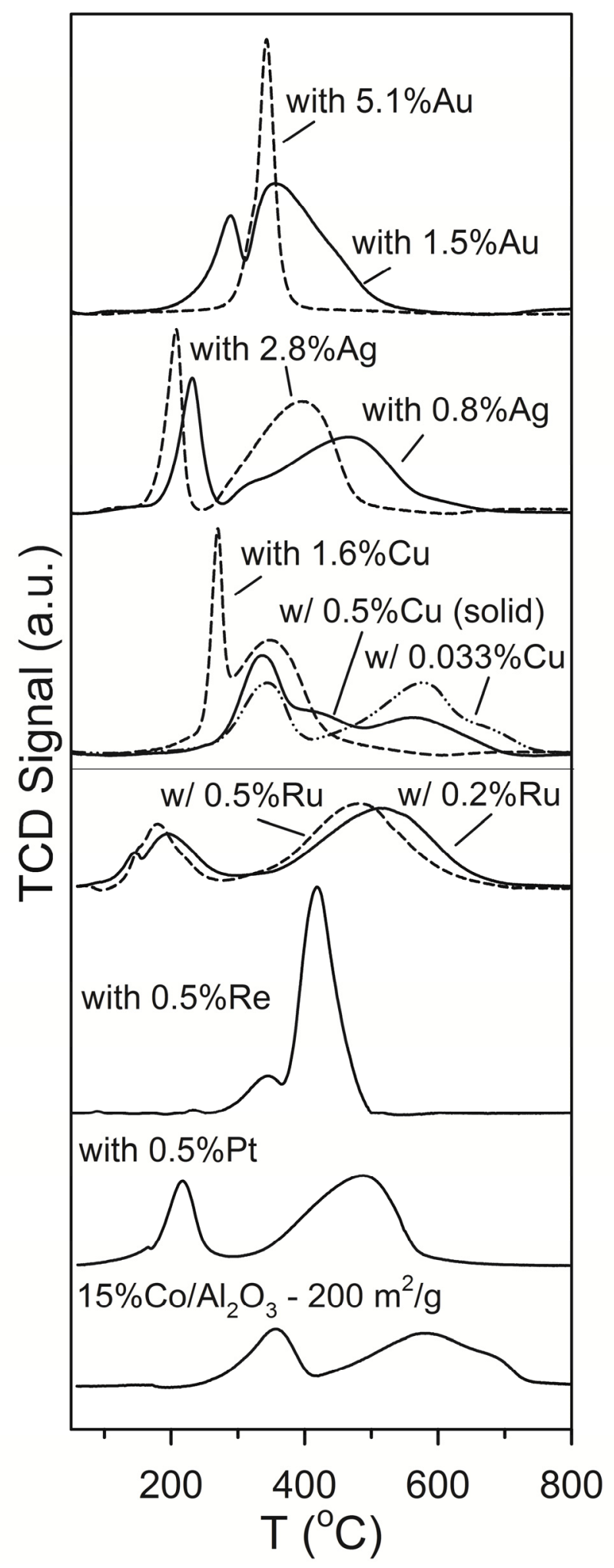


Figure 2. TPR profiles by Cook et al. [9] show that $\mathrm{Pt}$ and $\mathrm{Re}$ are more efficient than $\mathrm{Ru}$ in facilitating reduction of cobalt oxides over $25 \% \mathrm{Co} / \gamma-\mathrm{Al}_{2} \mathrm{O}_{3}$ catalysts with equivalent atomic loading (i.e., noble metal / Co ratio was 0.007 ).

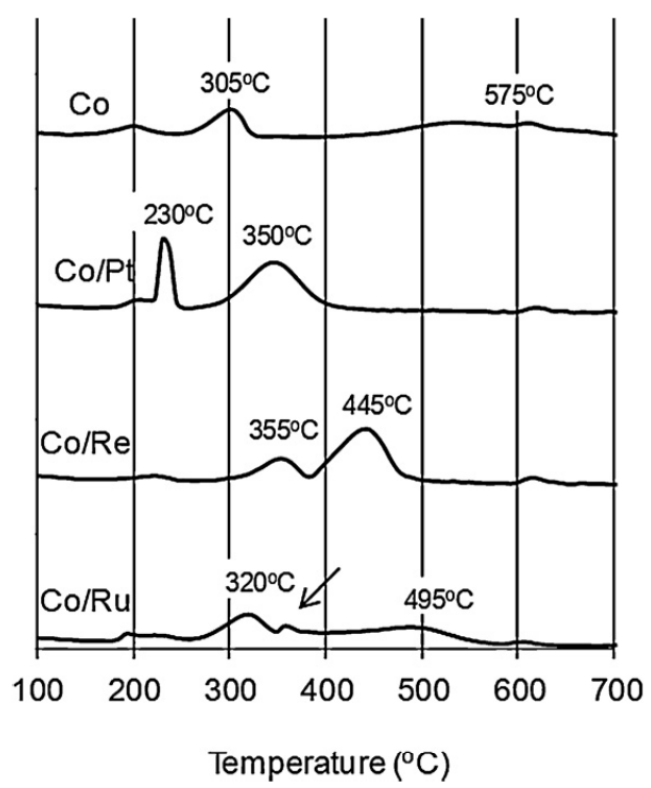

$\mathrm{Cu}, \mathrm{Ag}$, and $\mathrm{Au}$ (Group IB) promoters are also effective at promoting the reduction of cobalt oxides, as described in Figure 1 (top) [10]. However, note that the loadings indicated by the solid lines are approximately three times higher on an atomic basis than those of the commonly used promoters ( $\mathrm{Pt}, \mathrm{Re}, \mathrm{Ru}$ ) shown in the lower part of the figure. The costs of $\mathrm{Ag}$ and $\mathrm{Cu}$ are, whether on a weight or atomic basis, much lower than any of the other promoters shown. Therefore, it was of interest to explore their ability to facilitate reduction at even higher loadings. Increasing the loading by a factor of 3.3 resulted in further and important shifts of both TPR peaks of cobalt oxide reduction to lower temperatures (Figure 1, top).

The choice of promoter metal and its loading may influence the stability of cobalt catalysts in a number of ways. The first section examines how reduction promoter type and loading influence the activity and selectivity of cobalt catalysts, while the second section discusses how promoters may exacerbate deactivation rates through oxidation and a possible complex sintering mechanism, the two of which are not mutually exclusive. A brief summary of the application of computational methods is also provided, which discusses the location of promoter relative to cobalt, the resistance or sensitivity of cobalt to oxidation depending on size, and how promoters may hinder carbon formation pathways. Finally, in adding a second catalytic metal to the catalyst, the ability to regenerate the catalyst in a simple and effective manner becomes an important concern.

\subsection{Influence of Promoter Choice and Loading on Catalyst Activity and Selectivity}

\subsubsection{Example \#1-Copper}

The first example demonstrates a relatively inexpensive metal that is highly effective for promoting the reduction of cobalt oxides: $\mathrm{Cu}$, which is a common promoter in iron carbide FTS catalysts $[11,12]$. 
As of this writing, $\mathrm{Cu}$ is approximately $0.015 \%$ of the cost of Pt on a mass basis and would seem to be an ideal candidate as a promoter.

With increases in extent of reduction of cobalt (from $49.8 \%$ for $15 \% \mathrm{Co} / \mathrm{Al}_{2} \mathrm{O}_{3}$ to $53.2,69.4$, and $93.3 \%$ for $0.033 \%, 0.49 \%$, and $1.63 \% \mathrm{Cu}$-promoted $15 \% \mathrm{Co} / \mathrm{Al}_{2} \mathrm{O}_{3}$ catalysts, respectively) the active metal site densities with $\mathrm{Cu}$ addition increased also, and hydrogen chemisorption uptakes measured by TPD increased from $72 \mu \mathrm{mol} \mathrm{H} / \mathrm{g}_{\text {cat }}$ for the unpromoted $15 \% \mathrm{Co} / \mathrm{Al}_{2} \mathrm{O}_{3}$ catalyst to 82,140 , and $172 \mu \mathrm{m} \mathrm{H} / \mathrm{g}_{\text {cat }}$ for the $0.033 \%, 0.49 \%$, and $1.63 \% \mathrm{Cu}$-promoted $15 \% \mathrm{Co} / \mathrm{Al}_{2} \mathrm{O}_{3}$ catalysts [10]. However, the metal dispersions do not account for the partitioning of metal type on the surface of Co particles, or the influence of the presence of $\mathrm{Cu}$ on the ensembles of Co required for conducting the synthesis. Surface enrichment by $\mathrm{Cu}$ has been detected in bimetallic $\mathrm{Cu}$-Co catalysts before [13]

Table 1 shows a comparison of $\mathrm{X}_{\mathrm{CO}}$ at the same weight hourly space velocity of two Cu-promoted $15 \% \mathrm{Co} / \mathrm{Al}_{2} \mathrm{O}_{3}$ catalysts relative to the unpromoted $15 \% \mathrm{Co} / \mathrm{Al}_{2} \mathrm{O}_{3}$ catalyst. Despite increases in metal site densities as measured by hydrogen TPD, a decrease in $\mathrm{X}_{\mathrm{CO}}$ is observed, which is exacerbated at higher $\mathrm{Cu}$ loading [10]. These results suggest a poisoning of surface Co sites, likely due to enrichment of $\mathrm{Cu}$ at the surface. This finding is further supported by the changes in selectivity that occur when comparing the catalysts to the unpromoted catalyst at a similar conversion level. Table 2 shows that at the lower $\mathrm{Cu}$ promoter loading, the methane is slightly increased, $\mathrm{C}_{5}+$ is slightly decreased [10]. However, increasing the $\mathrm{Cu}$ promoter loading further leads to a prohibitive increase in methane selectivity (21.6\% versus $9.2 \%$ ) and a precipitous drop in $\mathrm{C}_{5}+$ selectivity (47.7\% versus $81.6 \%$ ) [10].

Table 1. $\mathrm{X}_{\mathrm{CO}}$ for two $\mathrm{Cu}$ promoted $15 \% \mathrm{Co} / \mathrm{Al}_{2} \mathrm{O}_{3}$ catalysts at a $\mathrm{SV}$ of $4.2 \mathrm{NL} / \mathrm{g}_{\text {cat }} / \mathrm{h}$ relative to the unpromoted catalyst. Conditions: $220{ }^{\circ} \mathrm{C}, 1.6 \mathrm{MPa}, \mathrm{H}_{2} / \mathrm{CO}=2.0$ (adapted with permission from [10] Copyright 2009, Elsevier).

\begin{tabular}{cccc}
\hline Catalyst & TOS (h) & $\mathbf{X}_{\mathbf{C O}}(\mathbf{\%})$ & $\begin{array}{c}\text { SV } \\
\left(\mathbf{N L} / \mathbf{g}_{\text {cat }} / \mathbf{h}\right)\end{array}$ \\
\hline $15 \% \mathrm{Co} / \mathrm{Al}_{2} \mathrm{O}_{3}$ & $26-98$ & 28.7 & 4.2 \\
$0.49 \% \mathrm{Cu}-15 \% \mathrm{Co} / \mathrm{Al}_{2} \mathrm{O}_{3}$ & $30-99$ & 27.9 & 4.2 \\
$1.63 \% \mathrm{Cu}-15 \% \mathrm{Co} / \mathrm{Al}_{2} \mathrm{O}_{3}$ & $25-104$ & 14.2 & 4.2 \\
\hline
\end{tabular}

Table 2. Two comparisons of product selectivity at similar $\mathrm{X}_{\mathrm{CO}}$ levels for two $\mathrm{Cu}$ promoted $15 \% \mathrm{Co} / \mathrm{Al}_{2} \mathrm{O}_{3}$ catalysts relative to the unpromoted catalyst. Conditions: $220{ }^{\circ} \mathrm{C}$, 1.6 $\mathrm{MPa}, \mathrm{H}_{2} / \mathrm{CO}=2.0$ (adapted with permission from [10] Copyright 2009, Elsevier).

\begin{tabular}{cccccc}
\hline Catalyst & $\mathbf{X}_{\mathbf{C O}}(\mathbf{\%})$ & $\begin{array}{c}\mathbf{S V} \\
\left(\mathbf{N L} / \mathbf{g}_{\text {cat }} / \mathbf{h}\right)\end{array}$ & $\mathbf{S}\left(\mathbf{C H}_{4}\right)$ & $\mathbf{S}\left(\mathbf{C}_{5}+\right)$ & $\mathbf{S}\left(\mathbf{C O}_{2}\right)$ \\
\hline $15 \% \mathrm{Co} / \mathrm{Al}_{2} \mathrm{O}_{3}$ & 47.8 & 2.0 & 8.9 & 80.6 & 0.82 \\
$0.49 \% \mathrm{Cu}-15 \% \mathrm{Co} / \mathrm{Al}_{2} \mathrm{O}_{3}$ & 50.6 & 1.7 & 9.9 & 76.6 & 0.83 \\
$15 \% \mathrm{Co} / \mathrm{Al}_{2} \mathrm{O}_{3}$ & 28.7 & 4.2 & 9.2 & 81.6 & 0.67 \\
$1.63 \% \mathrm{Cu}-15 \% \mathrm{Co} / \mathrm{Al}_{2} \mathrm{O}_{3}{ }^{*}$ & 29.9 & 1.0 & 21.6 & 47.7 & 1.51 \\
\hline
\end{tabular}

* Due to the low activity of the $1.63 \% \mathrm{Cu}$ promoted catalyst, a separate comparison was made at lower $\mathrm{X}_{\mathrm{CO}}$, as it was not possible to decrease SV further. 


\subsubsection{Example \#2-Silver and Gold}

A comparison between $\mathrm{Ag}$ and $\mathrm{Au}$ shows that, in the case of $\mathrm{Ag}$ promoted $15 \% \mathrm{Co} / \mathrm{Al}_{2} \mathrm{O}_{3}$, the catalyst achieves higher activity (Table 3 ) and $\mathrm{C}_{5}+$ selectivity (Table 4) than the unpromoted catalyst at both high and low loadings of promoter. $\mathrm{A} 15 \% \mathrm{Co} / \mathrm{Al}_{2} \mathrm{O}_{3}$ catalyst promoted with $1.51 \% \mathrm{Au}$ also performs better than the unpromoted catalyst with both an increase in productivity and a slight improvement in selectivities [10]. However, at a higher Au loading (5.05\%) the catalyst performed poorly with a steep drop in productivity (from $\mathrm{X}_{\mathrm{CO}}$ of 51.7 at $1.51 \% \mathrm{Au}$ to an $\mathrm{X}_{\mathrm{CO}}$ of 14.1 at $5.05 \% \mathrm{Au}$ at $\mathrm{SV}=4.2$, Table 3$)$ and adverse impacts on selectivity $\left(\mathrm{C}_{5}+\right.$ is $60.1 \%$ compared to $81.6 \%$ for the unpromoted catalyst at $\mathrm{X}_{\mathrm{CO}}$ of $\sim 28 \%$, Table 4) [10]. Thus, noble metal loading of promoter is important, not only from the standpoint of cost.

In a recent detailed kinetic investigation [14], which was a collaboration between CAER and Texas A\&M University in Qatar, modeling results point to the presence of two kinds of sites on the Co FTS catalyst for the production of methane-FTS sites from standard Anderson-Schulz-Flory kinetics and additional sites for methanation. The results of the Au promoted catalyst at the lower loading, and the Ag promoted catalysts at both low and high loadings, suggest that these Group IB promoters assist in either blocking methanation sites or controlling the relative surface fugacity of hydrogen relative to adsorbed $\mathrm{CO}$ and intermediates on the surface of the cobalt catalyst.

Table 3. $\mathrm{X}_{\mathrm{CO}}$ for two $\mathrm{Ag}$ and $\mathrm{Au}$-promoted $15 \% \mathrm{Co} / \mathrm{Al}_{2} \mathrm{O}_{3}$ catalysts at a $\mathrm{SV}$ of $4.2 \mathrm{NL} / \mathrm{g}_{\text {cat }} / \mathrm{h}$ relative to to the unpromoted catalyst. Conditions: $220^{\circ} \mathrm{C}, 1.6 \mathrm{MPa}, \mathrm{H}_{2} / \mathrm{CO}=2.0$ (adapted with permission from [10] Copyright 2009, Elsevier).

\begin{tabular}{cccc}
\hline Catalyst & TOS (h) & $\mathbf{X}_{\mathbf{C O}}(\mathbf{\%})$ & $\begin{array}{c}\text { SV } \\
\left(\mathbf{N L} / \mathbf{g}_{\text {cat }} / \mathbf{h}\right)\end{array}$ \\
\hline $15 \% \mathrm{Co} / \mathrm{Al}_{2} \mathrm{O}_{3}$ & $26-98$ & 28.7 & 4.2 \\
$1.51 \% \mathrm{Au}-15 \% \mathrm{Co} / \mathrm{Al}_{2} \mathrm{O}_{3}$ & $26-57$ & 51.7 & 4.2 \\
$5.05 \% \mathrm{Au}-15 \% \mathrm{Co} / \mathrm{Al}_{2} \mathrm{O}_{3}$ & $30-84$ & 14.1 & 4.2 \\
$0.83 \% \mathrm{Ag}-15 \% \mathrm{Co} / \mathrm{Al}_{2} \mathrm{O}_{3}$ & $20-47$ & 50.4 & 4.2 \\
$2.76 \% \mathrm{Ag}-15 \% \mathrm{Co} / \mathrm{Al}_{2} \mathrm{O}_{3}$ & $22-92$ & 46.9 & 4.2 \\
\hline
\end{tabular}

Table 4. Product selectivities for $\mathrm{Ag}$ and $\mathrm{Au}$-promoted $15 \% \mathrm{Co} / \mathrm{Al}_{2} \mathrm{O}_{3}$ catalysts at $\mathrm{X}_{\mathrm{CO}}$ values comparable to the unpromoted catalyst. Conditions: $220{ }^{\circ} \mathrm{C}, 1.6 \mathrm{MPa}, \mathrm{H}_{2} / \mathrm{CO}=2.0$ (adapted with permission from [10] Copyright 2009, Elsevier).

\begin{tabular}{cccccc}
\hline Catalyst & $\mathbf{X}_{\mathbf{C O}}(\mathbf{\%})$ & $\begin{array}{c}\mathbf{S V} \\
\left(\mathbf{N L} / \mathbf{g}_{\text {cat }} / \mathbf{h}\right)\end{array}$ & $\mathbf{S}\left(\mathbf{C H}_{4}\right)$ & $\mathbf{S}\left(\mathbf{C}_{5}+\right)$ & $\mathbf{S}\left(\mathbf{C O}_{\mathbf{2}}\right)$ \\
\hline $15 \% \mathrm{Co} / \mathrm{Al}_{2} \mathrm{O}_{3}$ & 47.8 & 2.0 & 8.9 & 80.6 & 0.82 \\
$1.51 \% \mathrm{Au}-15 \% \mathrm{Co} / \mathrm{Al}_{2} \mathrm{O}_{3}$ & 50.0 & 4.2 & 8.0 & 83.7 & 0.83 \\
$0.83 \% \mathrm{Ag}-15 \% \mathrm{Co} / \mathrm{Al}_{2} \mathrm{O}_{3}$ & 50.4 & 4.2 & 7.7 & 83.6 & 0.94 \\
$2.76 \% \mathrm{Ag}-15 \% \mathrm{Co}_{\mathrm{Al}_{2} \mathrm{O}_{3}}$ & 46.9 & 4.2 & 7.6 & 85.0 & 0.87 \\
$15 \% \mathrm{Co} / \mathrm{Al}_{2} \mathrm{O}_{3}$ & 28.7 & 4.2 & 9.2 & 81.6 & 0.67 \\
$5.05 \% \mathrm{Au}_{-}$ & 27.1 & 1.0 & 18.0 & 60.1 & 1.68 \\
\hline $15 \% \mathrm{Co} / \mathrm{Al}_{2} \mathrm{O}_{3}{ }^{*}$ & 27.0 & & \\
\hline
\end{tabular}

* Due to the low activity of the $5.05 \% \mathrm{Au}$ promoted catalyst, a separate comparison was made at lower $\mathrm{X}_{\mathrm{CO}}$, as it was not possible to decrease SV further. 


\subsubsection{Example \#3-Common Promoters (Pt, Re, Ru)}

Slight differences in selectivity can also be achieved with the commonly used reduction promoters, which are Pt, Re, and Ru [15], as compiled in Table 5. Ruthenium itself is catalytically active for the FTS reaction, and higher alpha values have been measured in the hydrocarbon distribution [16]. Therefore, it is not surprising that lower methane and higher $\mathrm{C}_{5}+$ were achieved with a $0.26 \% \mathrm{Ru}-25 \% \mathrm{Co} / \mathrm{Al}_{2} \mathrm{O}_{3}$ catalyst relative to an unpromoted one. Re promoter was also found to give slightly better selectivities, in agreement with the work of Borg et al. [17] (Table 6). However, an atomically equivalent amount of Pt slightly (though not prohibitively) worsened the selectivities, and an attempt to use Pd to replace Pt resulted in a significantly poorer product distribution.

Table 5. Product selectivities ${ }^{*}$ for $25 \% \mathrm{Co} / \mathrm{Al}_{2} \mathrm{O}_{3}$ catalysts containing commonly used promoters $(\mathrm{Pt}, \mathrm{Re}, \mathrm{Ru})$ or $\mathrm{Pd}$ at $\mathrm{X}_{\mathrm{CO}}$ values comparable an unpromoted reference catalyst. Conditions: $220^{\circ} \mathrm{C}, 2.2 \mathrm{MPa}, \mathrm{H}_{2} / \mathrm{CO}=2.1$ (adapted with permission from [15] Copyright 2012, Elsevier).

\begin{tabular}{ccccc}
\hline Catalyst & $\mathbf{X}_{\mathbf{C O}}(\mathbf{\%})$ & $\begin{array}{c}\mathbf{S V} \\
\left(\mathbf{N L} / \mathbf{g}_{\text {cat }} / \mathbf{h}\right)\end{array}$ & $\mathbf{S}\left(\mathbf{C H}_{\mathbf{4}}\right)$ & $\mathbf{S}\left(\mathbf{C}_{\mathbf{5}^{+}}\right)$ \\
\hline $25 \% \mathrm{Co} / \mathrm{Al}_{2} \mathrm{O}_{3}$ & 49.4 & 4.3 & 7.9 & 83.4 \\
$0.26 \% \mathrm{Ru}-25 \% \mathrm{Co} / \mathrm{Al}_{2} \mathrm{O}_{3}$ & 51.3 & 7.6 & 7.0 & 86.8 \\
$0.48 \% \mathrm{Re}-25 \% \mathrm{Co} / \mathrm{Al}_{2} \mathrm{O}_{3}$ & 49.6 & 8.0 & 7.2 & 86.0 \\
$0.50 \% \mathrm{Pt}-25 \% \mathrm{Co} / \mathrm{Al}_{2} \mathrm{O}_{3}$ & 48.0 & 5.6 & 8.3 & 83.0 \\
$0.27 \% \mathrm{Pd}-25 \% \mathrm{Co} / \mathrm{Al}_{2} \mathrm{O}_{3}$ & 50.3 & 4.9 & 11.5 & 75.9 \\
\hline
\end{tabular}

$* \mathrm{~S}\left(\mathrm{CO}_{2}\right)$ ranged from $0.35-0.75 \%$ in all catalysts. All data taken within first $81 \mathrm{~h}$ on-stream.

Table 6. Product selectivities from data taken at $210{ }^{\circ} \mathrm{C}, 2.0 \mathrm{MPa}, \mathrm{H}_{2} / \mathrm{CO}=2$, and $\mathrm{X}_{\mathrm{CO}}$ of $43-44 \%$ (adapted with permission from [17] Copyright 2009, Elsevier) over $20 \% \mathrm{Co} / \gamma-\mathrm{Al}_{2} \mathrm{O}_{3}$ catalysts without or with $0.5 \%$ Re using narrow pore $(7.4 \mathrm{~nm})$, medium pore $(12.3 \mathrm{~nm})$, and wide pore $(16.7 \mathrm{~nm})$ supports.

\begin{tabular}{cccc}
\hline Catalyst & \multicolumn{3}{c}{ Hydrocarbon selectivity (\%) } \\
& $\mathbf{C}_{\mathbf{1}}$ & $\mathbf{C}_{\mathbf{2}}-\mathbf{C}_{\mathbf{4}}$ & $\mathbf{C}_{\mathbf{5}^{+}}$ \\
$\mathrm{Co} / \mathrm{NPA}$ & 9.0 & 9.9 & 81.1 \\
$\mathrm{CoRe} / \mathrm{NPA}$ & 8.8 & 9.5 & 81.7 \\
$\mathrm{Co} / \mathrm{MPA}$ & 8.6 & 8.7 & 82.8 \\
$\mathrm{CoRe} / \mathrm{MPA}$ & 8.4 & 8.3 & 83.4 \\
$\mathrm{Co} / \mathrm{WPA}$ & 8.0 & 7.5 & 84.5 \\
$\mathrm{CoRe} / \mathrm{WPA}$ & 8.0 & 7.2 & 84.9 \\
\hline
\end{tabular}

In terms of differences in catalyst structure, the three commonly used promoters have, in a number of cases, been observed to be in atomic contact with Co (e.g., as an alloy), with no presence of promoter-promoter coordination at relatively low loadings ( $\operatorname{Re}$ [18-20], $\mathrm{Ru}$ [21], $\mathrm{Pt}$ [22-24]). This is not always the case (e.g., $\mathrm{Ru}[9,16]$ ), indicating that loading and preparation method are also factors that influence coordination environment. Pretreatment is also a factor. For example, Iglesia et al. [25] noted with $\mathrm{Ru}-\mathrm{Co} / \mathrm{TiO}_{2}$ catalysts that, with increasing calcination temperature, total coordination of $\mathrm{Ru}$ 
with neighbors increases to suggest sintering, but that most of the increase in coordination is due to $\mathrm{Ru}$ taking on coordination with Co; thus, calcination promoted mixing of the two metals.

Moreover, Chonco et al. [26] have recently demonstrated with physical mixtures of $\mathrm{Pt} / \mathrm{Al}_{2} \mathrm{O}_{3}$ and $\mathrm{Co} / \mathrm{Al}_{2} \mathrm{O}_{3}$ that atomic coordination of the promoter to cobalt is not always required to obtain a reduction promoting effect. In our work, unlike the $\mathrm{Re}, \mathrm{Ru}$, and $\mathrm{Pt}$ promoted $\mathrm{Co} /$ alumina catalysts at low promoter loadings, Pd promoter exhibited some promoter-promoter (i.e., Pd-Pd) coordination, suggesting the presence of well dispersed islands of $\mathrm{Pd}$ that likely gave rise to excessive hydrogenation activity [15] and rapid deactivation relative to the other three promoted catalysts [15].

Considering commercial research, a patent by Sasol researchers [1] examined Ru and Re promoters (of a catalyst containing $30 \mathrm{~g}$ Co and $100 \mathrm{~g} \mathrm{Al}_{2} \mathrm{O}_{3}$ ) at $0.41 \mathrm{~g}$ and $3.0 \mathrm{~g}$ levels, respectively, versus a catalyst containing just $0.05 \mathrm{~g}$ of $\mathrm{Pt}$ and reported slightly higher productivity with the Pt promoted catalyst $\left(0.349 \mathrm{~kg} \mathrm{HC} / \mathrm{kg}\right.$ cat $/ \mathrm{h}$ at $\mathrm{X}_{\mathrm{CO}}=87 \mathrm{vol} . \%$ with Pt versus 0.307 and $0.281 \mathrm{~kg} \mathrm{HC} / \mathrm{kg}$ cat $/ \mathrm{h}$ for $\mathrm{Ru}$ and $\mathrm{Re}$ at $\mathrm{X}_{\mathrm{CO}}=77$ and $70 \%$, respectively). The conditions were $220{ }^{\circ} \mathrm{C}, 2.0 \mathrm{MPa}, \mathrm{H}_{2} / \mathrm{CO}=2 / 1$; space velocity of $2.0 \mathrm{~m}_{\mathrm{n}}{ }^{3} / \mathrm{h} / \mathrm{kg}$ catalyst. Under the same conditions, similar productivity $(\sim 0.29 \mathrm{~kg} \mathrm{HC} / \mathrm{kg}$ cat $/ \mathrm{h}$ at $\mathrm{X}_{\mathrm{CO}}=73$ vol.\%) was observed with a $0.28 \mathrm{~g} \mathrm{Ru}$ as with $0.05 \mathrm{~g}$ Pt with catalysts of lower loading ( $20 \mathrm{~g} \mathrm{Co}$ and $100 \mathrm{~g} \mathrm{Al}_{2} \mathrm{O}_{3}$ ). The results appear to indicate that $\mathrm{Pt}$ is a very efficient promoter.

In a patent by Conoco researchers [27], the benefit of adding Re on selectivity was highlighted. Examples 27 through 31 in that patent compare $1 \% \mathrm{Re}$ promoted $20 \% \mathrm{Co} / \mathrm{Al}_{2} \mathrm{O}_{3}$ catalysts with an unpromoted catalyst. Higher conversions (77-100\%) and $\mathrm{C}_{5}+$ productivities $\left(240-270 \mathrm{~g} / \mathrm{h} / \mathrm{kg}_{\text {cat }}\right)$ for the Re promoted catalysts relative to the unpromoted catalyst $\left(\mathrm{X}_{\mathrm{CO}}\right.$ of $65 \%$ and $\mathrm{C}_{5}+$ productivity of $170 \mathrm{~g} / \mathrm{h} / \mathrm{kg}_{\text {cat }}$ ) were reported. In addition, improvements in selectivities were observed as well, including improvements in alpha (0.89-0.90 with Re promotion versus 0.88 for the unpromoted catalyst) and decreases in methane (9-15 wt.\% for Re promoted versus $18 \mathrm{wt} . \%$ for the unpromoted catalyst). Many other examples of Re promotion only or in combination with other elements are also highlighted in the patent report.

\subsubsection{Example \#4-Impact of Loading for Pt and Ag Promoted Catalysts}

The final example is provided to show that, just because the promoter forms promoter-promoter bonds (i.e., as in the case of Pd described in the previous subsection), it should not immediately be ruled out. Ag, by itself, is a catalyst that is only weakly active for hydrogenation, and its addition as a promoter does result in significant Ag-Ag coordination, but the resulting activity and selectivity of the Co catalyst is improved. Figure 3 (left) compares the Ag K-edge EXAFS Fourier transform magnitude spectra of $\mathrm{Ag}$-promoted $25 \% \mathrm{Co} / \mathrm{Al}_{2} \mathrm{O}_{3}$ catalysts as a function of $\mathrm{Ag}$ loading. While a lower distance peak for Ag-Co coordination is suggested (and confirmed by EXAFS fittings), with increasing loading of $\mathrm{Ag}$, the general trend in EXAFS fittings for Ag-promoted $25 \% \mathrm{Co} / \mathrm{Al}_{2} \mathrm{O}_{3}$ catalysts was increasing Ag-Ag coordination (higher distance peak), such that the $\mathrm{N}_{\mathrm{Ag}-\mathrm{Co}} / \mathrm{N}_{\mathrm{Ag}-\mathrm{Ag}}$ ratio decreased from 0.59 at $0.276 \% \mathrm{Ag}$ loading to 0.16 at $2.76 \% \mathrm{Ag}$ loading [28].

Figure 3 (right) compares the $\mathrm{Pt} \mathrm{L}_{\mathrm{III}}$-edge EXAFS Fourier transform magnitude spectra of Pt-promoted $25 \% \mathrm{Co} / \mathrm{Al}_{2} \mathrm{O}_{3}$ catalysts. A single low distance peak indicates primarily Pt-Co coordination, with no visible Pt-Pt coordination being evident. As shown in Table 7, as loading was increased for the Pt promoted catalyst, a slight negative impact on selectivity occurred, with a slight 
decrease in $\mathrm{C}_{5}+$ and a slight increase in the WGS rate [28]. For all Pt-promoted catalysts, slightly lower $\mathrm{C}_{5}+$ selectivities were observed compared to the unpromoted catalyst. With the Ag-promoted catalysts, $\mathrm{C}_{1}$ and $\mathrm{C}_{5}+$ selectivities were slightly improved at all loadings [28]. Thus, the presence of a weakly hydrogenating metal [29], Ag, did not adversely affect selectivity to a significant degree, even when excessive amounts of promoter were added [28].

In summary, the above examples show that (1) metals that facilitate reduction of cobalt oxides do not automatically increase $\mathrm{X}_{\mathrm{CO}}$ on a per gram of catalyst basis; (2) type and loading of promoter influence activity and selectivity such that a metal that may promote $\mathrm{X}_{\mathrm{CO}}$ (on a per $\mathrm{g}$ basis) at lower loading may or may not poison or adversely impact surface fugacities (and selectivity) at higher loadings; and (3) the intrinsic hydrogenation rate of the promoter is an important factor to consider, as it may adversely or beneficially influence selectivity.

\subsection{Influence of Promoter Addition on Oxidation and Complex Sintering of Cobalt}

\subsubsection{Reoxidation of Small Cobalt Crystallites at the Onset of FTS at Realistic Conversions}

The primary aims of adding a metal promoters are to (1) lower reduction temperature thereby increasing extent of reduction to Co metal and (2) boost active site densities by facilitating the reduction of cobalt oxide crystallites in strong interaction with the alumina support, such that clusters of cobalt metal crystallites can be formed to provide the active surface for carrying out the FTS reaction. Thus, when a promoter is added, the additional gain in active site density will be due in large part to the reduction of smaller cobalt oxide species having stronger interactions with the support. Depending on the loading of cobalt and method of preparation, if smaller cobalt metal crystallites (e.g., $<2-4.4 \mathrm{~nm}[30,31]$ ) within cobalt clusters are formed, they may be susceptible to reoxidation [30,32]. Some researchers have recently indicated that Co clusters less than 6-8 nm have lower intrinsic activity [33,34]. Additional investigations are needed in this area. At commercially relevant FTS conditions, a problem was identified by us in defining intrinsic activity; as chemisorption is conducted on freshly activated catalysts, any oxidation of such small Co clusters that occurs at commercially relevant conditions can mask a measurement of intrinsic activity at the level of the active site [35]. Therefore, it is important to take into account the oxidation state of Co in the working FTS catalyst.

To probe the role of oxidation, a recent XANES study was made whereby freshly reduced unpromoted and Pt-promoted cobalt/alumina catalysts were subjected to $\mathrm{H}_{2}: \mathrm{CO}: \mathrm{H}_{2} \mathrm{O}$ mixtures typical of the $50 \%$ conversion condition of a slurry phase reactor [36] for one hour. A lower-than-commercial loading of $10 \%$ cobalt was utilized in order to favor the formation of small cobalt crystallites after activation that fall in the range of being susceptible to reoxidation. The average cobalt cluster size (i.e., cluster of crystallites) was $\sim 5 \mathrm{~nm}$ [36]. Even though the $10 \% \mathrm{Co} / \mathrm{Al}_{2} \mathrm{O}_{3}$ catalyst was reduced at $550{ }^{\circ} \mathrm{C}$ as opposed to $400{ }^{\circ} \mathrm{C}$ for the $0.5 \% \mathrm{Pt}-10 \% \mathrm{Co} / \mathrm{Al}_{2} \mathrm{O}_{3}$ catalyst, the extent of reduction from XANES indicated that the Pt-promoted catalyst had a higher extent of reduction, as defined by the intensity of the white line. When switching to conditions to mimic 50\% conversion, the white line intensity in the XANES spectra of both catalysts increased significantly (Figure 4), but the change was more severe for the Pt-promoted catalyst [36]. This reoxidation occurred rapidly, is confined to a fraction of cobalt, and is not associated with the initial decay period commonly observed in FTS reaction tests, which 
may take on the order of days to establish. Reoxidation of the small cobalt crystallites $(<2-4.4 \mathrm{~nm})$ has been recently verified by in-situ XRD and magnetometer investigations [37].

Figure 3. (left) $\mathrm{Ag}$ promoted $25 \% \mathrm{Co} / \mathrm{Al}_{2} \mathrm{O}_{3}$ catalysts displayed EXAFS peaks that could only be fitted well by including both Ag-Co and Ag-Ag coordination; (right) Pt promoted $25 \% \mathrm{Co} / \mathrm{Al}_{2} \mathrm{O}_{3}$ catalysts displayed a single peak in the first coordination shell that could be fitted well by only including Pt-Co coordination (adapted with permission from [28] Copyright 2013, Elsevier).
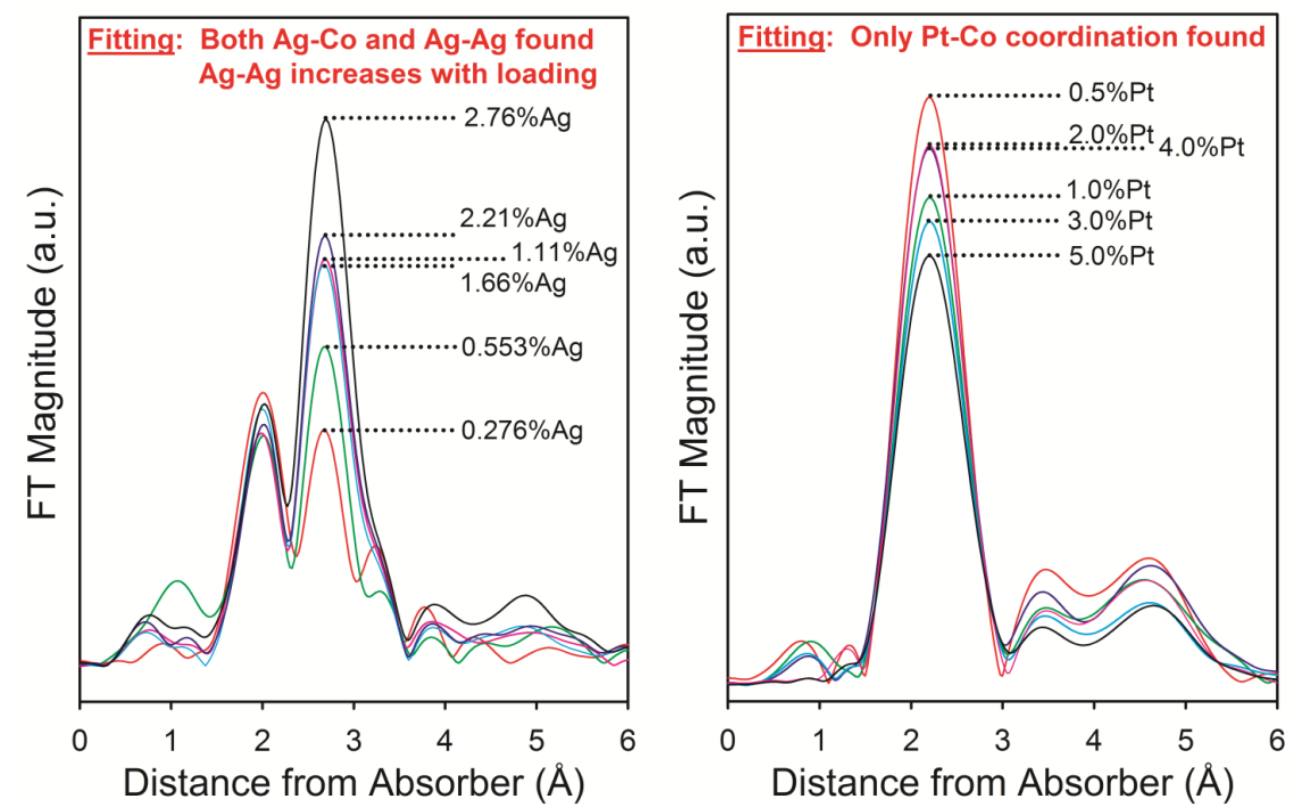

Table 7. Product selectivity * of $25 \% \mathrm{Co} / \mathrm{Al}_{2} \mathrm{O}_{3}$ catalysts having different loadings of $\mathrm{Ag}$ and Pt (adapted with permission from [28] Copyright 2013, Elsevier).

\begin{tabular}{cccccc}
\hline Catalyst & $\mathbf{X}_{\mathbf{C O}}(\mathbf{\%})$ & $\begin{array}{c}\mathbf{S V} \\
\left(\mathbf{N L} / \mathbf{g}_{\text {cat }} / \mathbf{h}\right)\end{array}$ & $\mathbf{S}\left(\mathbf{C H}_{4}\right)$ & $\mathbf{S}\left(\mathbf{C}_{\mathbf{5}}+\right)$ & $\mathbf{S}\left(\mathbf{C O}_{\mathbf{2}}\right)$ \\
\hline $25 \% \mathrm{Co} / \mathrm{Al}_{2} \mathrm{O}_{3}$ & 51.0 & $3.4-4.2$ & 8.3 & 82.5 & 0.8 \\
$0.5 \% \mathrm{Pt}-25 \% \mathrm{Co} / \mathrm{Al}_{2} \mathrm{O}_{3}$ & 52.0 & $1.7-12$ & 9.1 & 81.2 & 1.1 \\
$2.0 \% \mathrm{Pt}-25 \% \mathrm{Co} / \mathrm{Al}_{2} \mathrm{O}_{3}$ & 45.0 & $9.0-12$ & 9.1 & 81.9 & 1.1 \\
$5.0 \% \mathrm{Pt}-25 \% \mathrm{Co} / \mathrm{Al}_{2} \mathrm{O}_{3}$ & 52.5 & $10-16$ & 9.5 & 80.7 & 3.2 \\
$0.276 \% \mathrm{Ag}-25 \% \mathrm{Co} / \mathrm{Al}_{2} \mathrm{O}_{3}$ & 46.4 & $8.8-12$ & 7.4 & 84.1 & 0.4 \\
$1.11 \% \mathrm{Ag}-25 \% \mathrm{Co} / \mathrm{Al}_{2} \mathrm{O}_{3}$ & 48.1 & $9.3-12$ & 7.3 & 83.7 & 0.4 \\
$2.76 \% \mathrm{Ag}-25 \% \mathrm{Co} / \mathrm{Al}_{2} \mathrm{O}_{3}$ & 44.5 & $7.0-12$ & 7.6 & 84.1 & 0.6 \\
\hline
\end{tabular}

* All data taken within first $58 \mathrm{~h}$ on-stream. $T=220^{\circ} \mathrm{C} ; P=2.2 \mathrm{MPa} ; \mathrm{H}_{2} / \mathrm{CO}=2.1$. 
Figure 4. (left) Pt promoted and (right) unpromoted $10 \% \mathrm{Co} / \mathrm{Al}_{2} \mathrm{O}_{3}$ catalyst after (solid) hydrogen activation $\left(550{ }^{\circ} \mathrm{C}\right.$ for unpromoted and $400{ }^{\circ} \mathrm{C}$ for Pt-promoted) and (dashed) after exposure to $\mathrm{H}_{2}, \mathrm{CO}$, and $\mathrm{H}_{2} \mathrm{O}$ partial pressure ratios mimicking $\mathrm{X}_{\mathrm{CO}}=50 \%$ at $20.7 \mathrm{bar}$ (adapted with permission from [36] Copyright 2014, Springer).

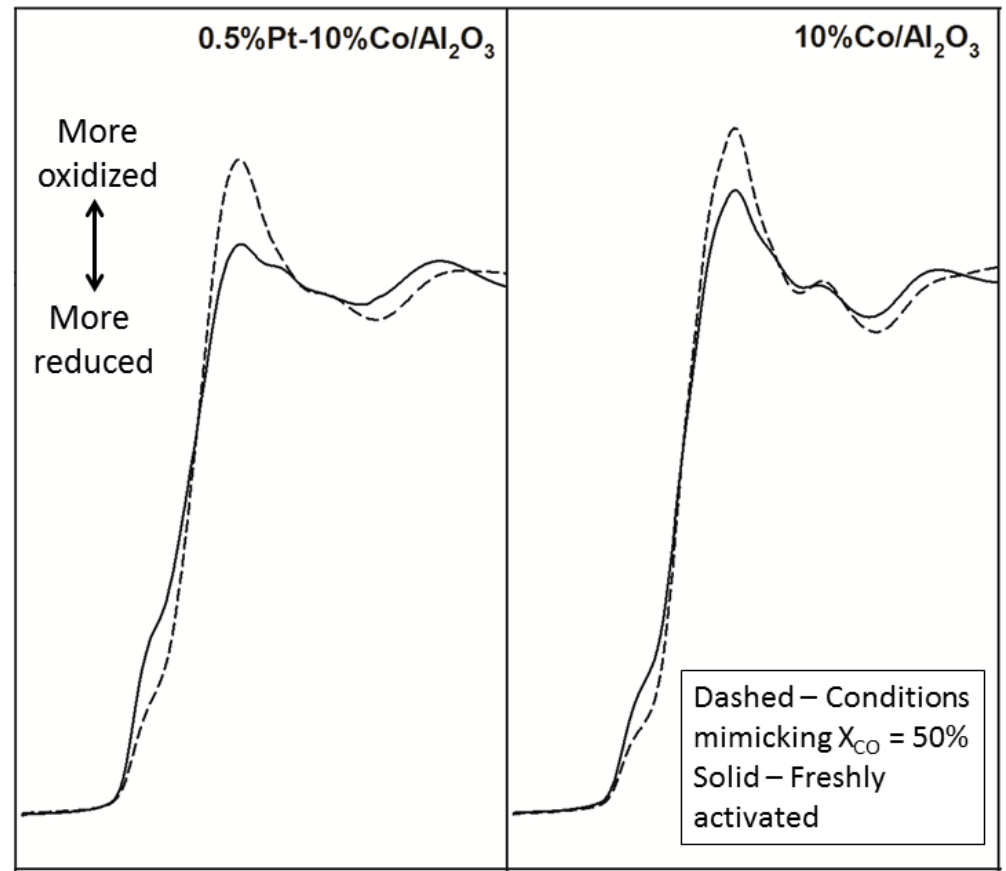

An extreme case in terms of small Co cluster size was also recently examined where Co particles were infused in the pores of KL-zeolite support by a CVD method [35] to produce a $0.5 \% \mathrm{Pt}-5 \% \mathrm{Co} / \mathrm{KL}$ catalyst with $1 \mathrm{~nm}$ cobalt particles. The catalyst, following activation in hydrogen, exhibited an extent of reduction of $75 \%$. However, after exposure to FTS conditions $\left(220^{\circ} \mathrm{C}, 1.8 \mathrm{MPa}, \mathrm{H}_{2} / \mathrm{CO} 1.95, \mathrm{SV}\right.$ of $3.0 \mathrm{NL} / \mathrm{g}_{\text {cat }} \mathrm{h}$ ), the extent of reduction fell to $33 \%$, as measured by XANES spectroscopy. A loss in Co-Co coordination and growth of Co-O coordination was quantified by EXAFS. $\mathrm{X}_{\mathrm{CO}}$ fell to 3.0\%, and the resulting product selectivities were very poor $\left(\mathrm{CH}_{4}\right.$ selectivity of $29.6 \%, \mathrm{C}_{5}+$ selectivity of $49.8 \%$, and $\mathrm{CO}_{2}$ selectivity of $3.4 \%$ ).

\subsubsection{Sintering and Co Support Compound Formation during Initial Deactivation Period Prior to} Leveling-off Period

The mechanisms of sintering during FTS on Co catalysts during typical commercial operation are not well understood and hence will not be discussed in detail in this review. There is evidence to indicate that $\mathrm{H}_{2} \mathrm{O}$ accelerates sintering of metallic particles [38-41]; on this aspect, a mechanism involving surface oxidation, coalescence, and formation of larger clusters has been postulated by Sadeqzadeh et al. [39]. Further research is needed in this area.

Unreduced cobalt oxide in the working FT catalyst could be problematic since it may coalesce, reduce, and provide a driving force for the sintering of cobalt metal particles; this leads to net reduction with time onstream in the initial catalyst decay period (i.e., which follows the onset period of $\sim 1 \mathrm{~h}$ as described in the previous section) [32,42]. Moreover, small cobalt oxide species can react with the support and contribute to the formation of cobalt aluminates $[42,43]$. Since a promoter can 
facilitate the reduction of smaller species that may, depending on size, be susceptible to reoxidation at high conversion (as previously described), any cobalt oxide formed at the onset can contribute to either net reduction/sintering with time on-stream or cobalt aluminate formation. Net reduction and changes in Co-Co coordination consistent with sintering were observed for a $0.2 \% \mathrm{Re}-15 \% \mathrm{Co} / \mathrm{Al}_{2} \mathrm{O}_{3}$ research catalyst at CAER during $2000 \mathrm{~h}$ of operation (Figure 5) [44,45]. Sintering, i.e., growth of Co metal crystallites, and carbon formation were observed by Saib et al. [31] during a 56-day commercial test of a $0.05 \% \mathrm{Pt} / 20 \% \mathrm{Co}$ catalyst. Sintering was determined to be rapid, reaching completion within the initial 15-16 days based on analysis by synchrotron-XRD of samples withdrawn from the reactor during this period; an increase in average crystallite diameter from 9 to $14 \mathrm{~nm}$ was observed. Formation in the catalyst of unreactive surface carbons, which restructured or poisoned the catalysts, occurred relatively more slowly over the 56-day period. Carbon deposits were analyzed by TPR during the latter part of this run [46]. During a second 140-day run [32], extent of reduction (EOR) was determined by periodically removing catalyst samples and analyzing them by XANES (Figure 6). EOR was determined to increase from 53 to $89 \%$ over the 140-day run. A small amount of cobalt aluminate formation was also observed, as it was detected in a used commercial $20 \% \mathrm{Co} / 0.05 \% \mathrm{Pt} / \mathrm{Al}_{2} \mathrm{O}_{3}$ catalyst [31]. Cobalt aluminate was also observed in used $0.2 \% \mathrm{Re}-15 \% \mathrm{Co} / \mathrm{Al}_{2} \mathrm{O}_{3}$ research catalyst samples $[44,47]$ (Figure 7).

Figure 5. (left) XANES and (right) EXAFS spectra as a function of time for a $0.2 \%$ Re$15 \% \mathrm{Co} / \mathrm{Al}_{2} \mathrm{O}_{3}$ catalyst. $T=220{ }^{\circ} \mathrm{C}, 2.0 \mathrm{MPa}, \mathrm{SV}=5 \mathrm{SL} / \mathrm{h} /$ gcat, $\mathrm{H}_{2} / \mathrm{CO}=2: 1$. Adapted with permission from [44] (Copyright 2003, Elsevier) and [45] (2006).
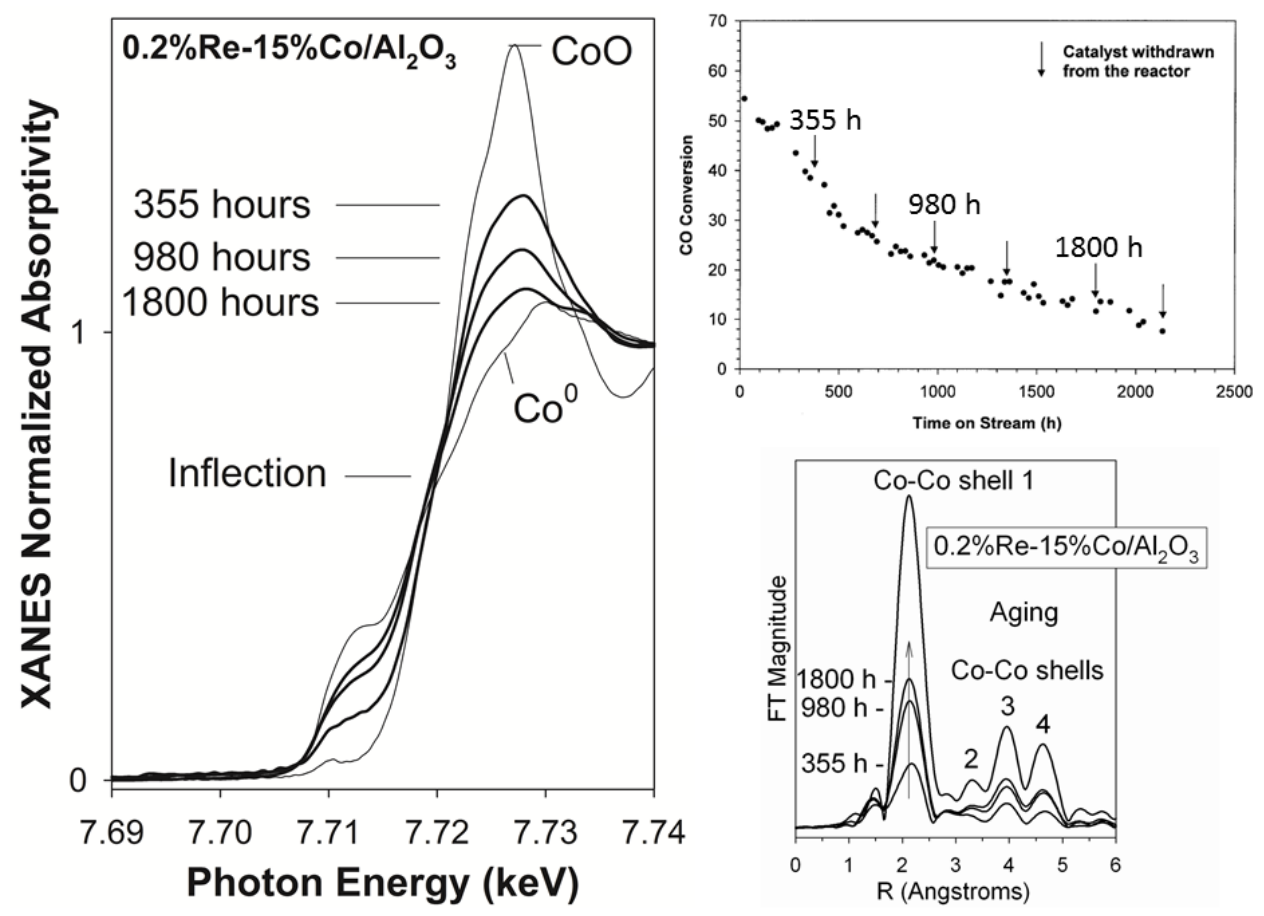

The impact of the promoter on cobalt aluminate formation from initially reduced small Co crystallites is difficult to assess, because unpromoted cobalt/alumina catalysts contain more residual unreduced $\mathrm{CoO}$ after activation, and this residual oxide, which is inactive for FTS, can also react with the support to form cobalt aluminate. Thus, there is a question as to how much cobalt aluminate is formed from the oxidation of very small (e.g., $<2-4.4 \mathrm{~nm}$ ) crystallites of cobalt metal at the onset of 
$\mathrm{CoO}$ formation (e.g., within the first hour, as shown in Figure 7 [44,45]) and its subsequent reaction with alumina, and how much is formed from the reaction of residual $\mathrm{CoO}$ (i.e., leftover due to incomplete reduction) with the support, as described by Sasol researchers [43]. The cobalt aluminate was detected by them in XANES derivative spectra, as shown in Figure 8. The results from the previous section suggest that the former is dependent on Co crystallite size and $\mathrm{P}\left(\mathrm{H}_{2} \mathrm{O}\right) / \mathrm{P}($ syngas $)$ ratio, which is in turn influenced by conversion level. In a recent kinetic investigation, excursions of a $\mathrm{Ru}$-promoted $25 \% \mathrm{Co} / \mathrm{Al}_{2} \mathrm{O}_{3}$ catalyst (average cluster size of $5.0 \mathrm{~nm}$ ) to high $\mathrm{CO}$ conversion levels (e.g., $\mathrm{X}_{\mathrm{CO}}>75 \%$ ) resulted in the oxidation of a fraction of cobalt clusters [21] (as demonstrated by changes in the lineshape of the XANES derivative spectra) and increases in $\mathrm{CO}_{2}$ and $\mathrm{CH}_{4}$ selectivities (Figure 9). The oxidized cobalt is active for WGS, and the additional $\mathrm{H}_{2}$ produced therefrom tends to increase the $\mathrm{C}_{1}$ product. Thus, there appears to be an unfavorable synergism in the selectivities of $\mathrm{CO}_{2}$ and $C_{1}$ when this threshold is surpassed (Figure 9) [21].

Crystallite size sensitivity for cobalt aluminate formation was also suggested in water co-feeding studies. Although $\mathrm{H}_{2} \mathrm{O}$ co-feeding can lead to improvements in activity and selectivity for certain cobalt catalysts [48], when a Pt promoter was utilized to facilitate the reduction of Co oxides in a $15 \% \mathrm{Co} / \mathrm{Al}_{2} \mathrm{O}_{3}$ catalyst (average cluster diameter $=5.6 \mathrm{~nm}$ ), at 28 vol.\% added $\mathrm{H}_{2} \mathrm{O}$ the catalyst underwent significant cobalt aluminate formation, as demonstrated in Figure 10 (left) and (right) [49,50] along with catastrophic deactivation ( $75 \%$ drop in $\mathrm{X}_{\mathrm{CO}}$ ). An unpromoted $25 \% \mathrm{Co} / \mathrm{Al}_{2} \mathrm{O}_{3}$ catalyst with larger cluster size (11.8 $\mathrm{nm}$ average diameter) [40] was more resistant to this phenomenon. Thus, on the one hand, a promoter is very useful for boosting $\mathrm{Co}^{\circ}$ site densities during activation when the support interaction with Co oxides is high. On the other hand, if the strongly interacting Co oxides are reduced and form tiny $\mathrm{Co}^{0}$ crystallites on the surface, they are more sensitive to $\mathrm{H}_{2} \mathrm{O}$. Higher loadings can help to make the catalyst more robust by increasing cobalt size, a technique that has been implemented commercially, and thereby reoxidation and subsequent Co aluminate formation may be largely avoided. With a commercial catalyst stabilized against these processes, only up to $\sim 3 \%$ cobalt aluminate was formed during realistic FTS conditions [31]. However, it should be noted that when exposed to $1.0 \mathrm{MPa} \mathrm{H}_{2} \mathrm{O}$ an increase was observed to $10 \%$ cobalt aluminate [43]; thus, water cofeeding or operating at high conversions may have drawbacks, depending on catalyst type and conditions utilized. A schematic of the structural changes discussed for research catalysts, including reoxidation of tiny $(<2-4.4 \mathrm{~nm})$ cobalt crystallites at the startup of Fischer-Tropsch synthesis at industrially relevant conversions, is shown in Figure 11 [42]. 
Figure 6. XANES analysis of a series of used $\mathrm{Co} / \mathrm{Pt} / \mathrm{Al}_{2} \mathrm{O}_{3}$ catalyst samples retrieved from a 100 barrel/day slurry bubble column reactor operated at $220^{\circ} \mathrm{C}, 2.0 \mathrm{MPa},\left(\mathrm{H}_{2}+\mathrm{CO}\right)$ and conversions between $50 \%$ and $70 \%$, feed gas composition $=50 \mathrm{vol} . \% \mathrm{H}_{2}$ and $25 \mathrm{vol} . \% \mathrm{CO}$, $\mathrm{P}\left(\mathrm{H}_{2} \mathrm{O}\right) / \mathrm{P}\left(\mathrm{H}_{2}\right)=1-1.5, \mathrm{P}\left(\mathrm{H}_{2} \mathrm{O}\right)=0.4-0.6 \mathrm{MPa}$. Reproduced with permission from [32]. Copyright (2006) Elsevier.

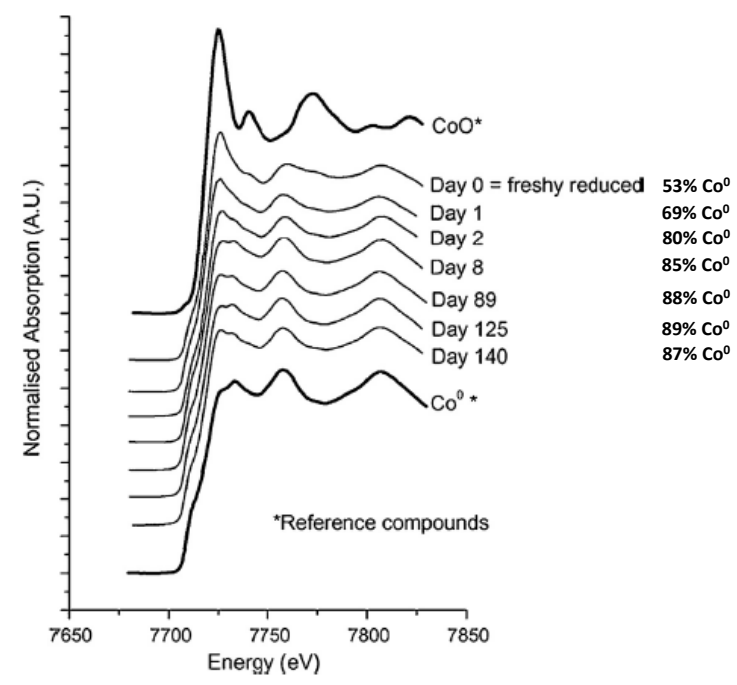

Figure 7. From the run shown in Figure 5, XANES derivative spectra of (left) freshly reduced/passivated catalysts, which could be fit with $\mathrm{Co}^{0}$ and $\mathrm{CoO}$, and (right) used catalyst samples, which could only be fitted with $\mathrm{Co}^{0}, \mathrm{CoO}$, and $\mathrm{CoAl}_{2} \mathrm{O}_{4}$. Adapted with permission from [44] (Copyright 2003, Elsevier) and [45] (2006).
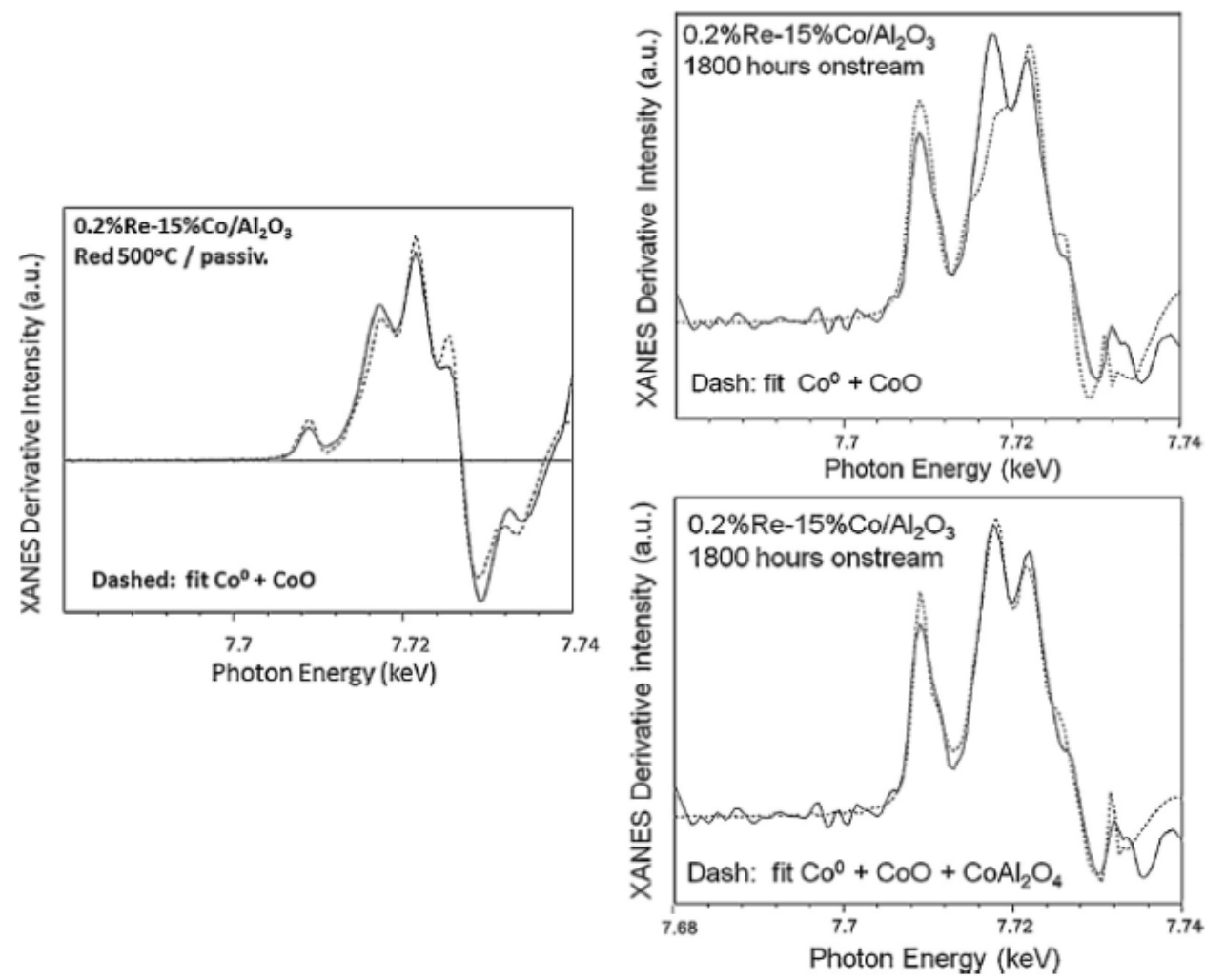
Figure 8. Formation of a minor cobalt aluminate component at $1.0 \mathrm{MPa} \mathrm{H}_{2} \mathrm{O}$ by increasing conversion in a continuously stirred tank reactor (CSTR) reactor run at $230{ }^{\circ} \mathrm{C}, 2.0 \mathrm{MPa}$, 50 vol.\% $\mathrm{H}_{2}, 25$ vol.\% $\mathrm{CO}$ and 25 vol.\% inerts. Reproduced with permission from [43]. Copyright (2011) Elsevier.



Figure 9. Changes in $\mathrm{CO}_{2}$ and $\mathrm{CH}_{4}$ selectivities as a function of conversion over $0.27 \% \mathrm{Ru}-$ $25 \% \mathrm{Co} / \mathrm{Al}_{2} \mathrm{O}_{3}$ catalyst ( $\mathrm{Co}$ cluster size of $\sim 5 \mathrm{~nm}$ by hydrogen chemisorption/pulse reoxidation) at $220{ }^{\circ} \mathrm{C}, 1.5 \mathrm{MPa}, \mathrm{H}_{2} / \mathrm{CO}=2.1$ and $\mathrm{SV}=0.3-15 \mathrm{NL} / \mathrm{g}_{\text {cat }}$ h (reproduced with permission from [21] Copyright 2011, Springer).
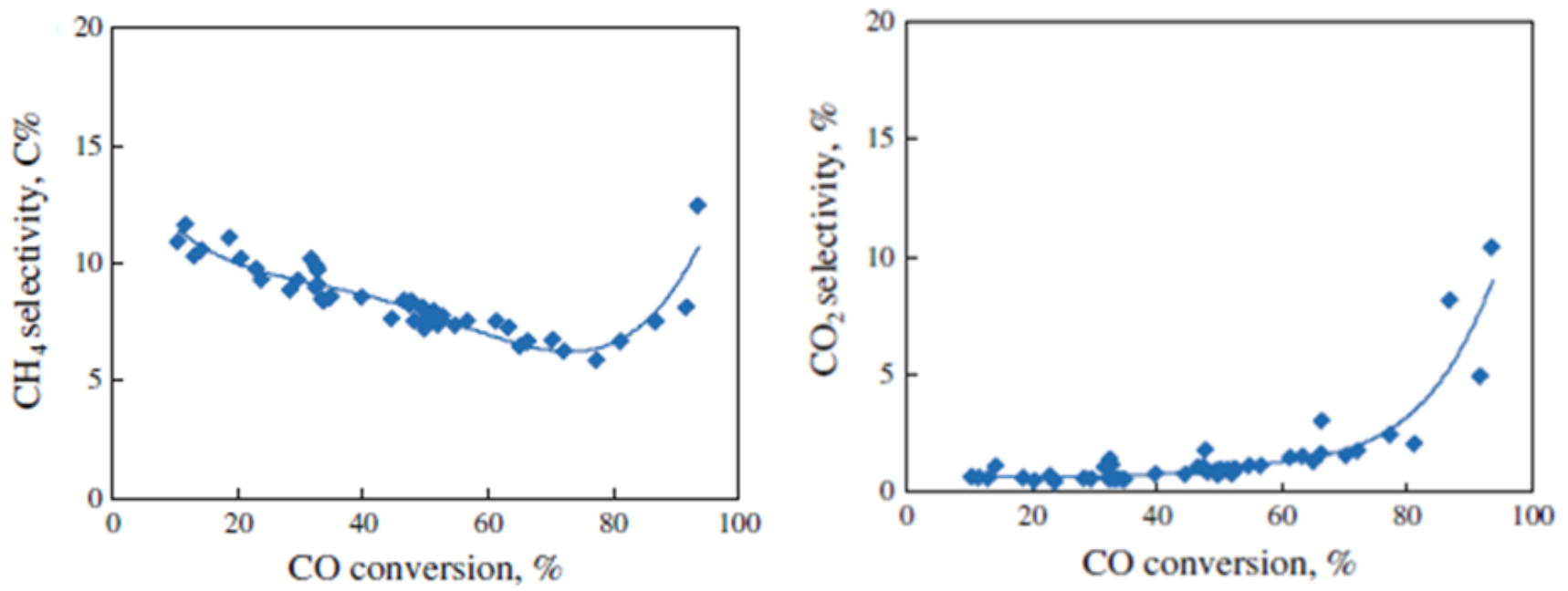
Figure 10. (left) Co-feeding of $\mathrm{H}_{2} \mathrm{O}$ over $0.5 \% \mathrm{Pt}-15 \% \mathrm{Co} / \mathrm{Al}_{2} \mathrm{O}_{3}$ at $T=210{ }^{\circ} \mathrm{C}, P=2.0$ $\mathrm{MPa}, \mathrm{H}_{2}: \mathrm{CO}=2: 1, \mathrm{SV}=8 \mathrm{SL} / \mathrm{g}_{\text {cat }}$ h reveals that irreversible deactivation (and a minor reversible effect) is observed at $28 \% \mathrm{H}_{2} \mathrm{O}$ addition; (right) XANES analysis of the used catalyst reveals formation of cobalt aluminate through reaction of the $\mathrm{CoO}$ formed with the support. Reprinted with permission from [40,49,50]. Copyright (2002, 2003, 2004) Elsevier.


Figure 11. Proposed explanation for the deactivation of alumina-supported cobalt nanoparticles in research catalysts as a function of time on-stream. Adapted with permission from [42]. Copyright (2013) Elsevier [42]. The figure emphasizes why commercial catalysts adopt larger crystallite diameters for the purpose of stability.

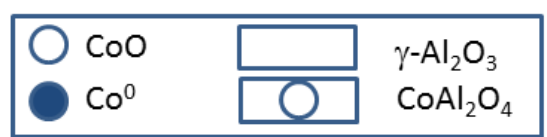

At onset of FTS reaction

After activation

$\mathrm{Co}_{\text {surface }}{ }_{\text {highest }}$
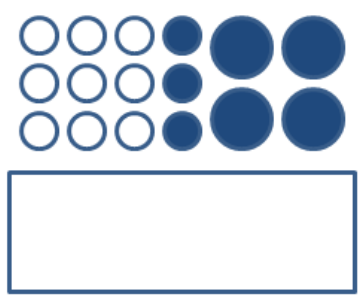

(b) Following from (a), coalesced $\mathrm{CoO}$ is formed; $\mathrm{Co}^{0}$ ripening/agglomeration

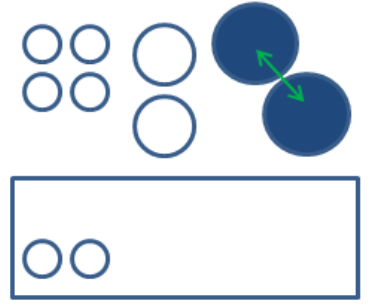

reoxidation of tiny crystallites (< 2 - 4.4. $\mathrm{nm})$ $\mathrm{Co}^{0}{ }_{\text {surface }}$ decreases

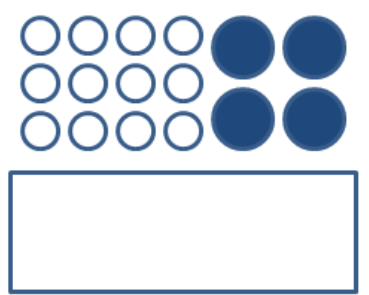

(c) Reduction of coalesced $\mathrm{CoO}$ and continuation of

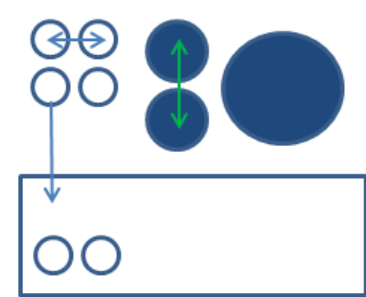

In early stages of FTS run preceding leveling off (a-d)

(a) sintering of $\mathrm{Co}^{\circ}$, coalescence of $\mathrm{CoO}$, and cobalt support compound formation $\mathrm{Co}^{0}{ }_{\text {surface }}$ decreases

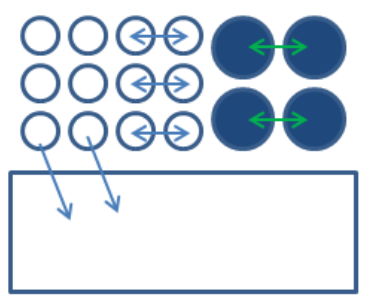

(d) ... and so on

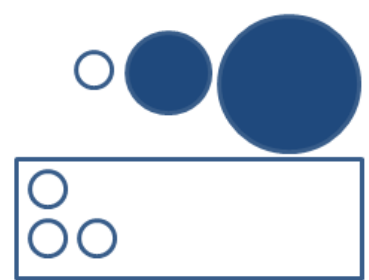




\subsection{Regeneration}

In recent years, there has been interest in carrying out oxidation-reduction cycles in order to explore the potential for regenerating metal promoted cobalt catalysts. In an earlier work [16], we simulated regeneration with $2 \% \mathrm{Ru}-15 \% \mathrm{Co}$ /alumina catalysts having relatively high $\mathrm{Ru}$ loadings. Part of the aim was to see if any promoter mixing or separation occurred at the atomic level, and the resulting influence on selectivity. To do so, TPR, EXAFS/XANES, and transmission electron microscopy with elemental mapping were applied. It was difficult to detect atomic mixing at the promoter loadings utilized, though elemental mapping showed that the metals were in close proximity to one another at the scale of nanometers. With reduction-oxidation cycles, TPR profiles revealed that while the first step of the TPR shifted to slightly higher temperatures, the second peak (i.e., $\mathrm{CoO}$ to $\mathrm{Co}^{0}$ ) shifted to slightly lower temperatures [16] for these heavily Ru-loaded catalysts.

Westrate et al. [51] compared $\mathrm{Pt}$ and $\mathrm{Ru}$ promoted $\mathrm{Co} /$ alumina catalysts subjected to oxidation-reduction treatments. Following oxidation treatment both the cobalt and promoter phases are well mixed and in an oxidized state. This finding is in agreement with our EXAFS results for a Ag-promoted Co/alumina catalyst [10]. Upon reduction, noble metals form bonds with cobalt metal, again in agreement with our earlier findings for $\mathrm{Pt}, \mathrm{Re}$, and $\mathrm{Ru}$ promoted catalysts at low promoter loadings [42]. During simulated regeneration by oxidation, the promoter separates from the cobalt phase and is found inside a ring of $\mathrm{Co}_{3} \mathrm{O}_{4}$, in "Kirkendall voids" as shown in Figure 12. Re-reduction of this state leads to a decrease in the promoter concentration at the surface of Co particles, as observed by XPS.

Figure 12. $\mathrm{Pt}$ promoter (oxide form) is separated from $\mathrm{Co}_{3} \mathrm{O}_{4}$ and found within Kirkendall voids within the $\mathrm{Co}_{3} \mathrm{O}_{4}$ particle. Reproduced with permission from [51]. Copyright (2013) Elsevier.



A key point regarding regeneration is whether or not the promoter continues to facilitate cobalt oxide reduction once an oxidation (e.g., carbon burn-off) step has been conducted. The proximity of the promoter to cobalt is important; although this will likely vary with promoter chemistry (see earlier comment regarding van Steen's group's use of physical mixtures to demonstrate that atomic contact may not be necessary in all cases [26]). To probe this attribute further, a TPR and XANES investigation was carried out to screen a number of promoter metals [52]. An example comparing two promoters- $\mathrm{Pt}$ and $\mathrm{Au}$ - is provided in Figure 13 to demonstrate the methodology. The oxidation-reduction cycle involved a $4 \mathrm{~h}$ calcination in flowing air at $350{ }^{\circ} \mathrm{C}$ followed by reduction for $10 \mathrm{~h}$ in hydrogen at 
$350{ }^{\circ} \mathrm{C}$. It is evident (Figure 13) that Pt improves its effectiveness after three oxidation-reduction cycles, while $\mathrm{Au}$ is no longer effective after the first cycle. In the case of $\mathrm{Au}$, the TPR profiles move to higher temperatures with increasing reduction-oxidation cycle number, suggesting that $\mathrm{Au}$ is separating from the Co (e.g., by sintering). At the same time, XANES shows that the oxidation state of Co following oxidation reduction moves toward higher oxidation state in the activated Au-promoted catalyst. The TPR profiles for Pt-promoted Co/alumina shift slightly to lower temperature. Corresponding XANES spectra demonstrate that the cobalt is largely reduced after activation following several simulated regeneration cycles. Thus, Pt is a more effective promoter for long-term use, although a different regeneration method at different conditions might be more effective in the case of Au. Both XANES and TPR data revealed that Re retains its ability to facilitate reduction even after 3 oxidation-reduction cycles. With $\mathrm{Ru}$, the XANES results indicated that $\mathrm{Ru}$ was also effective after 3 ORcycles, although a slight shift to higher temperature was observed for the $\mathrm{CoO}$ to $\mathrm{Co}^{0} \mathrm{TPR}$ peak position in the preliminary study [52].

Figure 13. (Top) TPR profiles after RO cycles and (Bottom) XANES profiles after RO cycling demonstrate that $\mathrm{Pt}$ is more effective at continuing to facilitate reduction after simulate regeneration. Reproduced with permission from [52]. Copyright (2014) Elsevier.
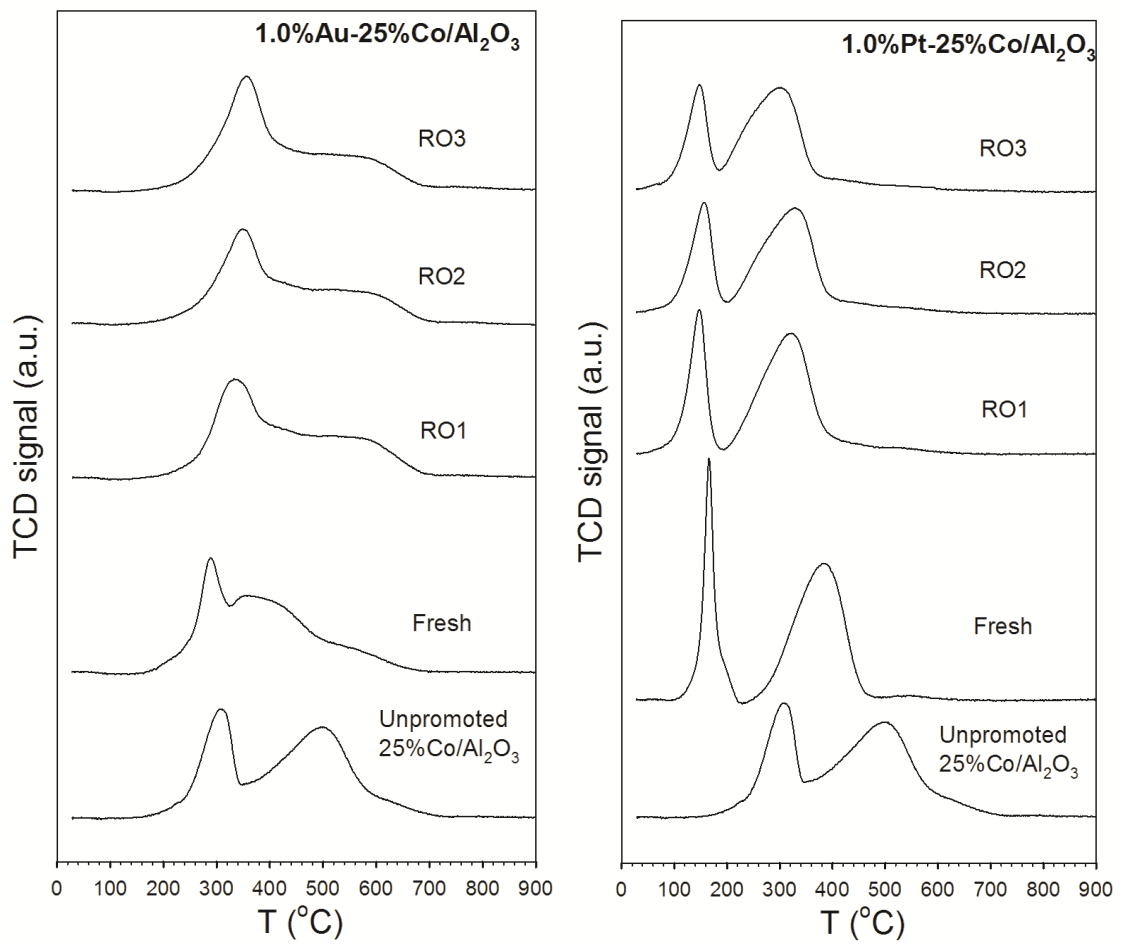
Figure 13. Cont.
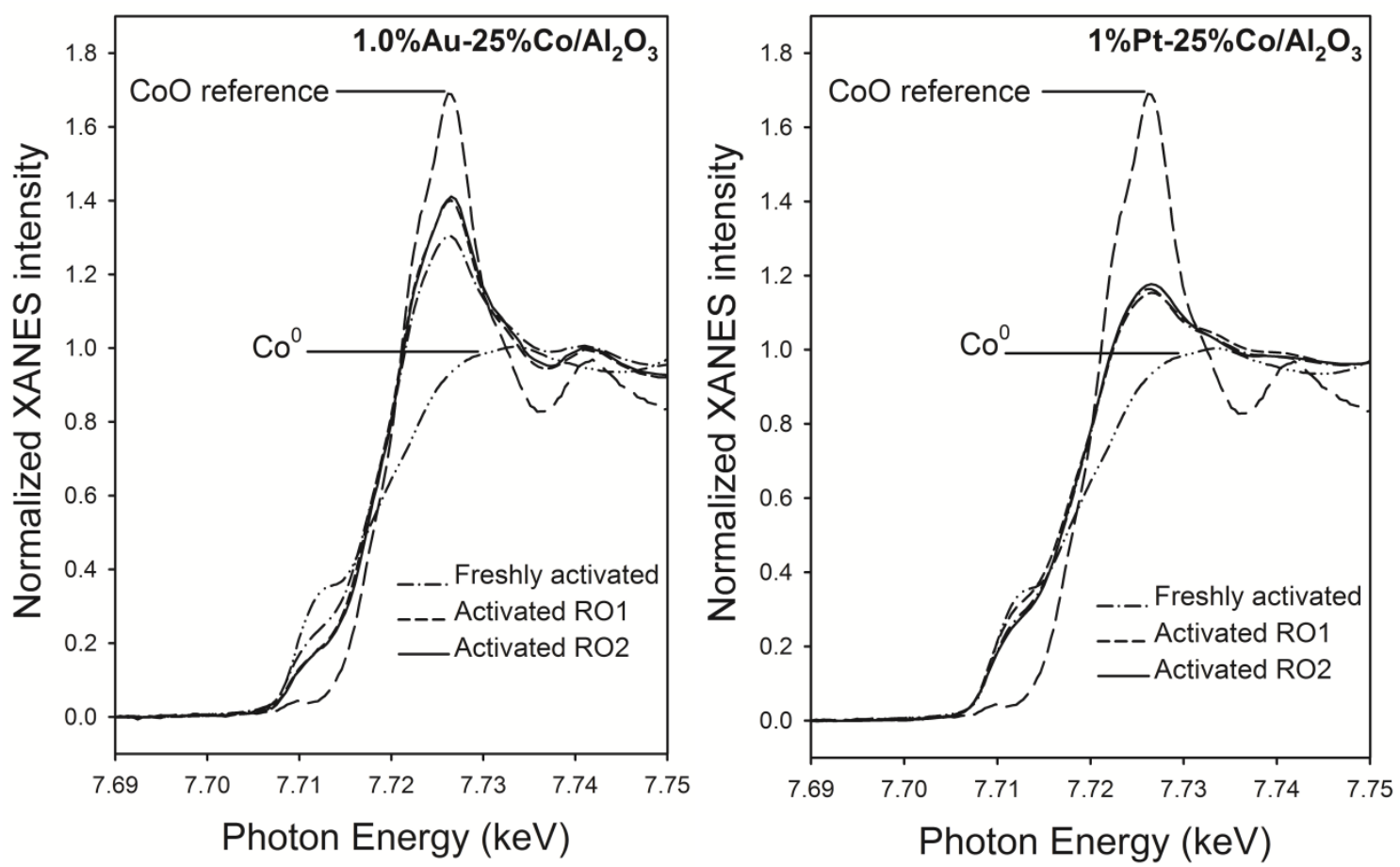

\subsection{Modeling}

\subsubsection{Modeling of Site Suppression and Deactivation}

Although this manuscript is focused on catalyst structure and its influence on FTS stability, a brief word should also be made regarding modeling. One puzzling aspect about the water effect during co-feeding and kinetic investigations is that it can be either positive or negative depending on the nature of the cobalt catalyst. Figure 10 displays results for a $0.5 \% \mathrm{Pt}$ promoted $15 \% \mathrm{Co} / \mathrm{Al}_{2} \mathrm{O}_{3}$ catalyst having an average cobalt cluster size of $5.6 \mathrm{~nm}$ (i.e., crystallites must be equal to below this value), and the water effect is negative but exhibits a significant degree of reversibility at levels below 28 vol.\% added $\mathrm{H}_{2} \mathrm{O}$. The reversibility was, based on EXAFS/XANES investigations, suggested to be due to oxidation and re-reduction of small cobalt crystallites. Because oxygen was bound to the cobalt sites, the behavior could be modeled in terms of a kinetic parameter based on adsorption inhibition of reactants. On the other hand, Co/silica catalysts having larger cobalt clusters exhibited a positive effect [53], and positive effects on cobalt catalysts have been suggested to be due to water increasing the concentration of surface active carbon species (e.g., unsupported Co and Co/titania [38]) or removing heavy wax from catalyst pores leading to a higher available site density (e.g., Co/silica with varying pore size [54]). Returning to cobalt/alumina catalysts, interestingly, by aging the catalyst sufficiently (i.e., the catalyst is significantly deactivated from its initial condition) [55] or utilizing catalysts with $10+\mathrm{nm}$ size [56], the deactivation rate becomes low, and the positive kinetic effect occurring on metallic cobalt particles can be observed. The main point is that the water effect can be modeled using a simple power law expression with a water effect parameter, $m$, and the magnitude and sign (i.e., positive [57] or negative [55,57]) of $m$ provides valuable information about the structure of the catalyst. 


$$
r(F T)=k P(\mathrm{CO})^{\mathrm{a}} P\left(\mathrm{H}_{2}\right)^{\mathrm{b}} /\left[1+m P\left(\mathrm{H}_{2} \mathrm{O}\right) / P\left(\mathrm{H}_{2}\right)\right]
$$

A number of the phenomena associated with the stability and deactivation of cobalt catalysts have been discussed herein, and these and other aspects of stability (e.g., carbon deposition and carbide formation) are discussed in the Editor's book on Catalyst Deactivation [58] and a review article [59]. At this point in time, a number of important aspects and trends regarding the structure sensitivity of cobalt catalysts, and especially experimental research catalysts, are known. However, moving forward, there is a great deal of focus on developing catalysts that make the most efficient use of cobalt. Co crystallites should be small enough to maximize active site density, but also large enough that crystallites will be stabilized against reoxidation and sintering. Researchers are also exploring preparation methods to disperse and adequately position metal clusters in spatially favorable ways (i.e., as far apart as possible). Some methods include freeze-drying [60], vapor phase impregnation [61], coating the support with carbon [62], using solvents such as ethylene glycol [63], optimizing drying temperature or calcination chemistry with dilute $\mathrm{NO} / \mathrm{N}_{2}$ [64], bypassing calcination altogether [53], or locking metal particles onto the support so that they cannot find one another and undergo agglomeration [65]. Thus, using advanced preparation methods to obtain spatially uniform distribution of cobalt crystallites is critical, since in conventional cobalt/alumina catalysts prepared by impregnation, cobalt clusters can be within close vicinity to one another, or in grapelike clusters, which have been described as "graveyards" for cobalt active sites during reaction testing [66]. Thus, thinking toward the future, it will be of increasing importance to model deactivation mechanisms and quantify how much each mechanism contributes to overall deactivation of the catalyst. Robust models which address the chemistry of promoters could enable the performance of new research catalysts to be compared to current commercial catalyst formulations. For example, a recently published forward thinking article by Argyle et al. [67] addresses modeling of the contributions of several deactivation mechanisms to overall deactivation rate in Co catalyzed FTS.

\subsubsection{Computational Methods Based on First Principles}

Related to promoters of FTS catalysts, computational methods based on first principles have been useful in describing the location of promoter with respect to cobalt, for providing insight into the requirements for cobalt oxidation by $\mathrm{H}_{2} \mathrm{O}$, and for determining how the promoter may influence carbon deposition.

Computational methods are being utilized to elucidate the preferential location for the occupancy of the promoter with respect to the cobalt atoms that make up the cluster. For example, a combined study making using of Low Energy Ion Scattering (i.e., on a $1 \% \mathrm{Re}-12 \% \mathrm{Co} / \mathrm{Al}_{2} \mathrm{O}_{3}$ catalyst) and computational DFT modeling (i.e., on a $\mathrm{Co}_{13} \mathrm{Re}$ cluster) determined that there is a preference of Re promoter to occupy subsurface sites, where it coordinates with a maximum number of cobalt atoms [68]. This is in agreement with the results of some EXAFS investigations, where direct Re-Co atomic contact has been observed [19,20].

Molecular modeling has also been conducted to examine surface oxidation of larger cobalt particles (e.g., as utilized in commercial catalysts) by $\mathrm{H}_{2} \mathrm{O}$, and the pathway was ruled out as a significant chemical transformation mechanism for deactivating sites under commercial FTS conditions [31]. 
Computational methods have also been used extensively to gain insight into the role of carbon deposits in catalyst deactivation. For example [69], HR-TEM and computational DFT modeling were applied to elucidate the preferred occupancies of carbon over different cobalt surfaces. The stability of various carbon species under reaction conditions was evaluated. Extended graphene islands and a surface carbide were found to be 99 and $79 \mathrm{~kJ} / \mathrm{mol}$ more stable than surface $\mathrm{CH}_{2}$ groups. Both carbon phases were suggested to initiate and grow from step sites. Saib et al. [31] have recently reviewed carbon formation in detail on cobalt FTS catalysts, including the application of computational methods. They also analyzed used catalysts from a commercial slurry bubble column reactor and, following wax extraction by THF, carried out temperature programmed hydrogenation and oxidation measurements to characterize the carbons. The least reactive species toward hydrogenation, which reacted at $430{ }^{\circ} \mathrm{C}$, was assigned to polymeric carbons. A model [70] showing the location of small carbon oligomers of the fcc $\operatorname{Co}(111)$ surface, the precursors of polymeric carbon, was described. Note that polymeric carbon was found on both cobalt and the support. The authors [31] also reviewed the role of subsurface carbon $[69,71]$, where theoretical modeling has indicated that subsurface carbon hinders $\mathrm{CO}$ adsorption and dissociation processes on associated Co atoms, and the requirements under which carbon induces clock surface reconstruction [72]. This, in turn, may cause deactivation of sites via shape changes or, on the other hand, induce the formation of active sites (e.g., B5 sites [31]: 3-fold sites that more easily dissociate $\mathrm{CO}$; or triangular nanoscale islands having step edges similar to $\mathrm{C} 7$ sites [73], as observed by scanning tunneling microscopy). The restructuring of cobalt by strong $\mathrm{CO}$ chemisorption (i.e., roughening — leading to more active sites) was described by Schulz et al. [74] as to be in competition with sintering.

Some computational studies have focused on defining how promoters of cobalt catalysts may impact carbon formation. Recently, the mechanisms for carbon compound formation on unpromoted and $\mathrm{Pt}$ or $\mathrm{Ru}$ promoted Co surfaces were investigated [75]. The activation energies for carbon-carbon and carbon-carbon-carbon coupling reactions were found to be larger on $\mathrm{Pt}$ or $\mathrm{Ru}$ promoted Co surfaces relative to unpromoted Co surface. The results suggest that carbon formation and thus, carbon compound (e.g., polymeric carbon formation, may be inhibited by the presence of the promoters. The authors also found that the promoters did not change the activation energy of $\mathrm{C}$ diffusion to the subsurface.

\section{Experimental Section}

Typical catalyst preparation method: the support used was Sasol Catalox-150 $\gamma-\mathrm{Al}_{2} \mathrm{O}_{3}$. It was first calcined at $400{ }^{\circ} \mathrm{C}$ in a muffle furnace for $4 \mathrm{~h}$. A slurry impregnation method was performed, whereby the ratio of the volume of loading solution used to the weight of alumina was 1:1, such that approximately 2.5 times the pore volume of solution was used to prepare the catalyst in two steps [7]. Due to the solubility limit of cobalt nitrate, multiple impregnation steps were used. After each impregnation step, the catalyst was dried under vacuum in a rotary evaporator from 80 to $100{ }^{\circ} \mathrm{C}$. Promoter precursors used were tetraammine palladium (II) nitrate, tetraammine platinum (II) nitrate, rhenium oxide $\left(\mathrm{Re}_{2} \mathrm{O}_{7}\right)$, ruthenium nitrosyl nitrate, silver nitrate, $\mathrm{HAuCl}_{4}$, and copper nitrate. The promoters were added dropwise to achieve incipient wetness impregnation. After final drying at $80-100{ }^{\circ} \mathrm{C}$, the final catalysts were calcined at $350^{\circ} \mathrm{C}$ under flowing air for $4 \mathrm{~h}$. 
Typical CSTR reaction test: the catalyst (15 g) was ground and sieved to 170-325 mesh before loading into a fixed-bed reactor for $10-15 \mathrm{~h}$ of ex situ reduction at $350{ }^{\circ} \mathrm{C}$ and atmospheric pressure using a gas mixture of $\mathrm{H}_{2} / \mathrm{He}$ with a molar ratio of $1: 3$. The reduced catalyst was then transferred to a 1-L continuously stirred tank reactor (CSTR) which was previously charged with $315 \mathrm{~g}$ of melted Polywax 3000 , under the protection of a $\mathrm{N}_{2}$ inert gas. The transferred catalyst was further reduced in situ at $230^{\circ} \mathrm{C}$ at atmospheric pressure using pure hydrogen for another $10 \mathrm{~h}$ before starting the FT reaction. In this study, the FT conditions were $220{ }^{\circ} \mathrm{C}, 1.5-2.2 \mathrm{MPa}, \mathrm{H}_{2} / \mathrm{CO}=2.0-2.1$. The space velocity varied between 1.0 and $16 \mathrm{NL} / \mathrm{g}$-cat/h. in order to give about $50 \% \mathrm{CO}$ conversion in different tests. This allowed us to fairly compare the differences in hydrocarbon selectivity data resulting from the promoter effect.

\section{Conclusions}

There are a number of stability issues that must be considered when selecting metal reduction promoters for use in Fischer-Tropsch synthesis catalysts. If tiny cobalt crystallites $(<2-4.4 \mathrm{~nm})$ are formed by facilitating the reduction of cobalt oxides that are strongly interacting with the support, they may undergo reoxidation at the onset of FTS at high conversion. Any cobalt oxide either left unreduced or formed from reoxidation of tiny cobalt crystallites can participate in a complex sintering mechanism that involves agglomeration of cobalt oxides, re-reduction, and sintering of the metal. Promoters can also exacerbate sintering if the cobalt metal clusters formed as a result of the promoting effect are in close proximity to other cobalt particles on the surface. Not all metals that facilitate cobalt reduction promote activity on a per gram catalyst basis; some will poison the surface (e.g., $\mathrm{Cu}$ ). A poor choice of promoter (or poor choice in loading) can also lead to excessive hydrogenation activity and raise the light gas selectivity (e.g., $\mathrm{Pd}$ or $\mathrm{Cu}$; $\mathrm{Au}$ at high loading). Furthermore, certain metals (e.g., $\mathrm{Au}$ ) that promote cobalt oxide reduction can separate from cobalt during oxidation-reduction (regeneration) cycles. Therefore, they may not be effective for long-term use, or they may require non-standard regeneration treatments. Computational studies suggest that certain promoters (e.g., Pt or Ru) may hinder deactivation by carbon by increasing the energy barrier for carbon-carbon coupling reactions, while subsurface $\mathrm{C}$ formation was not found to be affected.

\section{Acknowledgments}

The authors would like to acknowledge the support of the Commonwealth of Kentucky. We would also like to thank the Editor for helpful comments.

\section{Conflicts of Interest}

The authors declare no conflict of interest.

\section{References}

1. Espinoza, R.L.; Visagie, J.L.; van Berge, P.J.; Bolder, F.H. Fischer-Tropsch catalysts containing iron and cobalt. US Patent No. 5,733,839, March 1998. 
2. Van Berge, P.J.; Barradas, S.; van de Loosdrecht, J.; Visagie, J.L. Advances in the cobalt catalyzed Fischer-Tropsch synthesis. Erdöl Erdgas Kohle 2001, 117, 138-142.

3. Wang, W.-J.; Chen, Y.-W. Influence of metal loading on the reducibility and hydrogenation activity of cobalt/alumina catalysts. Appl. Catal. 1991, 77, 223-233.

4. Jacobs, G.; Ji, Y.; Davis, B.H.; Cronauer, D.C.; Kropf, A.J.; Marshall, C.L. Fischer-Tropsch synthesis: Temperature programmed EXAFS/XANES investigation of the influence of support type, cobalt loading, and noble metal promoter addition to the reduction behavior of cobalt oxide particles. Appl. Catal. A 2007, 333, 177-191.

5. Reuel, R.C.; Bartholomew, C.H. The stoichiometries of $\mathrm{H}_{2}$ and $\mathrm{CO}$ adsorptions on cobalt: Effects of support and preparation. J. Catal. 1984, 85, 63-77.

6. Vada, S.; Hoff, A.; Adnanes, E.; Schanke, D.; Holmen, A. Fischer-Tropsch synthesis on supported cobalt catalysts promoted by platinum and rhenium. Top. Catal. 1995, 2, 155-162.

7. Jacobs, G.; Das, T.K.; Zhang, Y.-Q.; Li, J.; Racoillet, G.; Davis, B.H. Fischer-Tropsch synthesis: support, loading, and promoter effects on the reducibility of cobalt catalysts. Appl. Catal. A 2002, 233, 263-281.

8. Farrauto, R.J.; Bartholomew, C.H. Fundamentals of Industrial Catalytic Processes; John Wiley \& Sons: Chichester, UK, 2003; p. 700.

9. Cook, K.M.; Poudyal, S.; Miller, J.T.; Bartholomew, C.H.; Hecker, W.C. Reducibility of aluminasupported cobalt Fischer-Tropsch catalysts: Effects of noble metal type, distribution, retention, chemical state, bonding, and influence on cobalt crystallite size. Appl. Catal. A 2012, 449, 69-80.

10. Jacobs, G.; Ribeiro, M.C.; Ma, W.; Ji, Y.; Khalid, S.; Sumodjo, P.T.A.; Davis, B.H. Group 11 $(\mathrm{Cu}, \mathrm{Ag}, \mathrm{Au})$ promotion of $15 \% \mathrm{Co} / \mathrm{Al}_{2} \mathrm{O}_{3}$ Fischer-Tropsch synthesis catalysts. Appl. Catal. A 2009, 361, 137-151.

11. Aldossary, M.A.; Sharma, P.; Ojeda, M.; Gupta, M.; Fierro, J.L.; Spivey, J.J. Effect of different $\mathrm{Cu}$ loading on Fe-Mg catalyst for Fischer-Tropsch synthesis. In Proceedings of ACS National Meeting \& Exposition, Philadelphia, PA, USA, August 19-23, 2012. Curran Associates, Inc.: Red Hook, NY, USA, 2012; Volume 57, p. 944.

12. Li, S.; Li, A.; Krishnamoorthy, S.; Iglesia, E. Effects of $\mathrm{Zn}, \mathrm{Cu}$, and $\mathrm{K}$ promoters on the structure and on the reduction, carburization, and catalytic behavior of iron-based Fischer-Tropsch synthesis catalysts. Catal. Lett. 2001, 77, 197-205.

13. Cesar, D.V.; Perez, C.A. Quantitative XPS analysis of bimetallic Cu-Co catalysts. Phys. Status Solidi A 2001, 187, 321-326.

14. Todic, B.; Bhatelia, T.; Froment, G.F.; Ma, W.; Jacobs, G.; Davis, B.H.; Bukur, D.B. Kinetic model of Fischer-Tropsch synthesis in a slurry reactor on $\mathrm{Co} / \mathrm{Re} / \mathrm{Al}_{2} \mathrm{O}_{3}$ catalyst. Ind. Eng. Chem. Res. 2013, 52, 669-679.

15. Jacobs, G.; Ma, W.; Gao, P.; Todic, B.; Bhatelia, T.; Bukur, D.B.; Khalid, S.; Davis, B.H. Fischer-Tropsch synthesis: differences observed in local atomic structure and selectivity with $\mathrm{Pd}$ compared to typical promoters $\left(\mathrm{Pt}, \mathrm{Re}, \mathrm{Ru}\right.$ ) of $\mathrm{Co} / \mathrm{Al}_{2} \mathrm{O}_{3}$ catalysts. (Special Issue in honor of the late Prof. Laszlo Guczi 1932-2012). Top. Catal. 2012, 55, 811-817. 
16. Jacobs, G.; Sarkar, A.; Ji, Y.; Luo, M.-S.; Dozier, A.; Davis, B.H. Fischer-Tropsch synthesis: assessment of the ripening of cobalt clusters and mixing between $\mathrm{Co}$ and $\mathrm{Ru}$ promoter via oxidation-reduction cycles over lower Co-loaded $\mathrm{Ru}-\mathrm{Co} / \mathrm{Al}_{2} \mathrm{O}_{3}$ catalysts. Ind. Eng. Chem. Res. 2008, 47, 672-680.

17. Borg, O.; Hammer, N.; Eri, S.; Lindvag, O.A.; Myrstad, R.; Blekkan, E.A.; Ronning, M.; Rytter, E.; Holmen, A. Fischer-Tropsch synthesis over un-promoted and Re-promoted gamma- $\mathrm{Al}_{2} \mathrm{O}_{3}$ supported cobalt catalysts with different pore sizes. Catal. Today 2009, 142, 70-77.

18. Bazin, D.; Borko, L.; Koppany, Zs.; Kovacs, I.; Stefler, G.; Sajo, L.I.; Schay, Z.; Guczi, L. $\mathrm{Re}-\mathrm{Co} / \mathrm{NaY}$ and $\mathrm{Re}-\mathrm{Co} / \mathrm{Al}_{2} \mathrm{O}_{3}$ bimetallic catalysts: In situ EXAFS and catalytic activity. Catal. Lett. 2002, 84, 169-182.

19. Jacobs, G.; Chaney, J.A.; Patterson, P.M.; Das, T.K.; Davis, B.H. Fischer-Tropsch synthesis: Study of the promotion of $\mathrm{Re}$ on the reduction property of $\mathrm{Co} / \mathrm{Al}_{2} \mathrm{O}_{3}$ catalysts by in situ EXAFS/XANES of $\mathrm{Co} \mathrm{K}$ and $\mathrm{Re} \mathrm{L}_{\mathrm{III}}$ edges and XPS. Appl. Catal. A 2004, 264, 203-212.

20. Ronning, M.; Nicholson, D.G.; Holmen, A. In situ EXAFS study of the bimetallic interaction in a rhenium-promoted alumina-supported cobalt Fischer-Tropsch catalyst. Catal. Lett. 2001, 72, 141-146.

21. Ma, W.; Jacobs, G.; Ji, Y.; Bhatelia, T.; Bukur, D.B.; Khalid, S.; Davis, B.H. Fischer-Tropsch synthesis: Influence of $\mathrm{CO}$ conversion on selectivities, $\mathrm{H}_{2} / \mathrm{CO}$ usage ratios, and catalyst stability for a $\mathrm{Ru}$ promoted $\mathrm{Co} / \mathrm{Al}_{2} \mathrm{O}_{3}$ catalyst using a slurry phase reactor. Top. Catal. 2011, 54, 757-767.

22. Guczi, L.; Bazin, D.; Kovacs, I.; Borko, L.; Schay, Z.; Lynch, J.; Parent, P.; Lafon, C.; Stefler, G.; Koppany, Z.; Sajo, I. Structure of $\mathrm{Pt}-\mathrm{Co} / \mathrm{Al}_{2} \mathrm{O}_{3}$ and $\mathrm{Pt}-\mathrm{Co} / \mathrm{NaY}$ bimetallic catalysts: Characterization by in situ EXAFS, TPR, XPS and by activity in CO (Carbon Monoxide) Hydrogenation. Top. Catal. 2002, 20, 129-139.

23. Jacobs, G.; Chaney, J.A.; Patterson, P.M.; Das, T.K.; Maillot, J.C.; Davis, B.H. Fischer-Tropsch synthesis: Study of the promotion of $\mathrm{Pt}$ on the reduction property of $\mathrm{Co} / \mathrm{Al}_{2} \mathrm{O}_{3}$ catalysts by in situ EXAFS of Co K and Pt L III edges and XPS. J. Synch. Rad. 2004, 11, 414-422.

24. Sadeqzadeh, M.; Karaca, H.; Safonova, O.V.; Fongarland, P.; Chambrey, S.; Roussel, P.; GribovalConstant, A.; Lacroix, M.; Curulla-Ferré, D.; Luck, F.; et al. Identification of the active species in the working alumina-supported cobalt catalyst under various conditions of Fischer-Tropsch synthesis. Catal. Today 2011, 164, 62-67.

25. Iglesia, E.; Soled, S.L.; Fiato, R.A.; Via, G.H. Bimetallic synergy in cobalt-ruthenium Fischer-Tropsch synthesis catalysts. J. Catal. 1993, 143, 345-368.

26. Chonco, Z.H.; Nabaho, D.; Claeys, M.; van Steen, E. The role of reduction promoters in Fischer-Tropsch catalysts for the production of liquid fuels. In Proceedings of 23rd Meeting of the North American Catalysis Society, 2-7 June 2013, Louisville, KY, USA.

27. Ionkina, O.; Subramanian, M.A.; Chao, W.; Makar, K.M.; Manzer, L.E. Fischer-Tropsch processes and catalysts with promoters. US Patent 20020010221A1, January 2002. 
28. Jermwongratanachai, T.; Jacobs, G.; Ma, W.; Shafer, W.D.; Gnanamani, M.K.; Gao, P.; Kitiyanan, B.; Davis, B.H.; Klettlinger, J.L.S.; Yen, C.H.; et al. Fischer-Tropsch synthesis: Comparisons between $\mathrm{Pt}$ and $\mathrm{Ag}$ promoted $\mathrm{Co} / \mathrm{Al}_{2} \mathrm{O}_{3}$ catalysts for reducibility, local atomic structure, catalytic activity, and oxidation-reduction (OR) cycles. Appl. Catal. 2013, 464-465, 165-180.

29. Redjala, T.; Remita, H.; Apostolescu, G.; Mostafavi, M.; Thomazeau, C.; Uzio, D. Bimetallic $\mathrm{Au}-\mathrm{Pd}$ and Ag-Pd clusters synthesized by gamma or electron beam radiolysis and study of the reactivity/structure relationships in the selective hydrogenation of but-1,3-diene. Oil Gas Sci. Technol. 2006, 61, 789-797.

30. Van Steen, E.; Claeys, M.; Dry, M.E.; van de Loosdrecht, J.; Viljoen, E.L.; Visagie, J.L. Stability of nanocrystals: thermodynamic analysis of oxidation and re-reduction of cobalt in water/hydrogen mixtures. J. Phys. Chem. B 2005, 109, 3575-3577.

31. Saib, A.M.; Moodley, D.J.; Ciobica, I.M.; Hauman, M.M.; Sigwebela, B.H.; Weststrate, C.J.; Niemantsverdriet, J.W.; van de Loosdrecht, J. Fundamental understanding of deactivation and regeneration of cobalt Fischer-Tropsch synthesis catalysts. Catal. Today 2010, 154, 271-282.

32. Saib, A.M.; Borgna, A.; van de Loosdrecht, J.; van Berge, P.J.; Niemantsverdriet, J.W. XANES study of the susceptibility of nano-sized cobalt crystallites to oxidation during realistic FischerTropsch synthesis. Appl. Catal. 2006, 312, 12-19.

33. Bezemer G.L, Bitter J.H.; Kuipers H.P.C.E.; Oosterbeek H.; Holewijn J.E.; Xu X.D.; Kapteijn, F.; van Dillen, A.J.; de Jong, K.P. Cobalt particle size effects in the Fischer-Tropsch reaction studied with carbon nanofiber supported catalysts. J. Am. Chem. Soc. 2006, 128, 3956-3964.

34. Borg, Ø.; Dietzel, P.D.C.; Spjelkavik, A.I.; Tveten, E.Z.; Walmsley, J.C.; Diplas, S.; Eri, S.; Holmen, A.; Rytter, E. Fischer-Tropsch synthesis: cobalt particle size and support effects on intrinsic activity and product distribution. J. Catal. 2008, 259, 161-164.

35. Azzam, K.; Jacobs, G.; Ma, W.; Davis, B.H. Effect of cobalt particle size on the catalyst intrinsic activity for Fischer-Tropsch synthesis. Catal. Lett. 2014, 144, 389-394.

36. Jermwongratanachai, T.; Jacobs, G.; Shafer, W.D.; Ma, W.; Pendyala, V.R.R.; Davis, B.H.; Kitiyanan, B.; Khalid, S.; Cronauer, D.C.; Kropf, A.J.; Marshall, C.L. Fischer-Tropsch synthesis: Oxidation of a fraction of cobalt crystallites in research catalysts at the onset of FT at partial pressures mimicking 50\% CO conversion. Top. Catal. in press.

37. Fischer, N.; Clapham, B.; Feltes, T.E.; van Steen, E.; Claeys, M. The reoxidation of cobalt Fischer-Tropsch catalysts. In Proceedings of Syngas 2012 Convention, Cape Town, South Africa, 1-4 April 2012.

38. Bertole, C.J.; Mims, C.A.; Kiss, G. The effect of water on the cobalt-catalyzed Fischer-Tropsch synthesis. J. Catal. 2002, 210, 84-96.

39. Sadeqzadeh, M.; Hong, J.; Fongarland, P.; Curulla-Ferre, D.; Luck, F.; Bousquet, J.; Schweich, D.; Khodakov, A.Y. Mechanistic modeling of cobalt based catalyst sintering in a fixed bed reactor under different conditions of Fischer-Tropsch synthesis. Ind. Eng. Chem. Res. 2012, 51, 11955-11964.

40. Jacobs, G.; Das, T.K.; Patterson, P.M.; Luo, M.; Conner, W.A.; Davis, B.H. Fischer-Tropsch synthesis: Effect of water on $\mathrm{Co} / \mathrm{Al}_{2} \mathrm{O}_{3}$ catalysts and XAFS characterization of reoxidation phenomena. Appl. Catal. A 2004, 270, 65-76. 
41. Soled, S.; Kliewer, C.; Kiss, G.; Baumgartner, J. Reversible and irreversible changes in Co Fischer-Tropsch catalysts during synthesis. In Proceedings of 21st Meeting of the North American Catalysis Society, San Francisco, CA, USA, 7-12 June 2009.

42. Jacobs, G.; Ma, W.; Gao, P.; Todic, B.; Bhatelia, T.; Bukur, D.B.; Davis, B.H. The application of synchrotron methods in characterizing iron and cobalt Fischer-Tropsch synthesis catalysts. Catal. Today 2013, 214, 100-139.

43. Moodley, D.J.; Saib, A.M.; van de Loosdrecht, J.; Welker-Nieuwoudt, C.A.; Sigwebela, B.H.; Niemantsverdriet, J.W. The impact of cobalt aluminate formation on the deactivation of cobalt-based Fischer-Tropsch synthesis catalysts. Catal. Today 2011, 171, 192-200.

44. Das, T.K.; Jacobs, G.; Patterson, P.M.; Conner, W.A.; Davis, B.H. Fischer-Tropsch synthesis: Characterization and catalytic properties of rhenium promoted cobalt alumina catalysts. Fuel 2003, 82, 805-815.

45. Jacobs, G.; Sarkar, A.; Ji, Y.; Patterson, P.M.; Das, T.K.; Luo, M.; Davis, B.H. Fischer-Tropsch synthesis: characterization of interactions between reduction promoters and $\mathrm{Co}$ for $\mathrm{Co} / \mathrm{Al}_{2} \mathrm{O}_{3}-$ based GTL catalysts. In Proceedings of AIChE Annual Meeting, San Francisco, CA, USA, 12-17 November 2006.

46. Karaca, H.; Hong, J.; Fongarland, P.; Roussel, P.; Griboval-Constant, A.; Lacroix, M.; Hortmann, K.; Safonova, O.V.; Khodakov, A.Y. In situ XRD investigation of the evolution of alumina-supported cobalt catalysts under realistic conditions of Fischer-Tropsch synthesis. Chem. Commun. 2010, 46, 788-790.

47. Jacobs, G.; Patterson, P.M.; Zhang, Y.-Q.; Das, T.K.; Li, J.; Davis, B.H. Fischer-Tropsch synthesis: Deactivation of noble metal-promoted $\mathrm{Co} / \mathrm{Al}_{2} \mathrm{O}_{3}$ catalysts. Appl. Catal. A 2002, 233, 215-226.

48. Kim, C.J. Water addition for increased $\mathrm{CO} / \mathrm{H}_{2}$ hydrocarbon activity over catalysts comprising * e There is virtually no difference. carried out for thousands of hours, the time ranges specified are very close to each othecobalt, ruthenium, and mixtures thereof which may include a promoter metal. U.S. Patent 5,227,407, July 1993.

49. Li, J.; Zhan, X.; Zhang, Y.-Q.; Jacobs, G.; Das, T.K.; Davis, B.H. Fischer-Tropsch synthesis: Effect of water on the deactivation of $\mathrm{Pt}$ promoted $\mathrm{Co} / \mathrm{Al}_{2} \mathrm{O}_{3}$ catalysts. Appl. Catal. A 2002, 228, 203-212.

50. Jacobs, G.; Das, T.K.; Patterson, P.M.; Li, J.; Sanchez, L.; Davis, B.H. Fischer-Tropsch synthesis: XAFS studies of the effect of water on a Pt-promoted $\mathrm{Co} / \mathrm{Al}_{2} \mathrm{O}_{3}$ catalyst. Appl. Catal. A 2003, $247,335-343$.

51. Weststrate, C.J.; Saib, A.M.; Niemantsverdriet, J.W. Promoter segregation in Pt and Ru promoted cobalt model catalysts during oxidation-reduction treatments. Catal. Today 2013, 215, 2-7.

52. Jermwongratanachai, T.; Jacobs, G.; Shafer, W.D.; Pendyala, V.R.R.; Ma, W.; Gnanamani, M.K.; Hopps, S.; Thomas, G.A.; Kitiyanan, B.; Khalid, S.; et al. Fischer-Tropsch synthesis: TPR and XANES analysis of the impact of oxidation-reduction (OR) cycles on the reducibility of Co/alumina catalysts with different promoters (Pt, Ru, Re, Ag, Au, Rh, Ir). Catal. Today 2014, in press. 
53. Li, J.; Jacobs, G.; Das, T.K.; Zhang, Y.-Q.; Davis, B.H. Fischer-Tropsch synthesis: Effect of water on the catalytic properties of a $\mathrm{Co} / \mathrm{SiO}_{2}$ catalyst. Appl. Catal. A 2002, 236, 67-76.

54. Dalai, A.K.; Das, T.K.; Chaudhari, K.V.; Jacobs, G.; and Davis, B.H. Fischer-Tropsch synthesis: Water effects on Co supported on wide and narrow-pore silica. Appl. Catal. A 2005, 289, $135-142$.

55. Ma, W.; Jacobs, G.; Sparks, D.E.; Spicer, R.L.; Davis, B.H.; Klettlinger, J.L.S.; Yen, C.H. Fischer-Tropsch synthesis: Kinetics and water effect study over $25 \% \mathrm{Co} / \mathrm{Al}_{2} \mathrm{O}_{3}$ catalysts. Catal. Today 2014, in press.

56. Logdberg, S.; Boutonnet, M.; Walmsley, J.C.; Jaras, S.; Holmen, A.; Blekkan, E.A. Effect of water on the space-time yield of different supported cobalt catalysts during Fischer-Tropsch synthesis. Appl. Catal. A 2011, 393, 109-121.

57. Ma, W.; Jacobs, G.; Sparks, D.E.; Gnanamani, M.K.; Pendyala, V.R.R.; Yen, C.H.; Klettlinger, J.L.S.; Tomsik, T.M.; Davis, B.H. Fischer-Tropsch synthesis: support and cobalt cluster size effects on kinetics over $\mathrm{Co} / \mathrm{Al}_{2} \mathrm{O}_{3}$ and $\mathrm{Co} / \mathrm{SiO}_{2}$ catalysts. Fuel 2011, 90, 756-765.

58. Studies in Surface Science and Catalysis. Catalyst Deactivation 1991: Proceedings of the 5th International Symposium; Bartholomew, C.H., Butt, J.B., Eds.; Elsevier: Amsterdam, The Netherlands, 1991; Volume 68.

59. Bartholomew, C.H. Mechanisms of catalyst deactivation. Appl. Catal. A 2001, 212, 17-60.

60. Eggenhuisen, T.M.; Munnik, P.; Talsma, H.; de Jongh, P.E.; de Jong, K.P. Freeze-drying for controlled nanoparticle distribution in $\mathrm{Co} / \mathrm{SiO}_{2}$ Fischer-Tropsch catalyst. J. Catal. 2013, 297, 306-313.

61. Graham, U.M.; Jacobs, G.; Gnanamani, M.; Lipka, S.; Shafer, W.D.; Swartz, C.; Jermwongratanachai, T.; Chen, R.; Rogers, F.; Davis, B.H. Fischer Tropsch Synthesis: High Oxygenate-Selectivity of Cobalt Catalysts supported on Hydrothermal Carbons. ACS Catal. submitted for publication, 2014.

62. van de Loosdrecht, J.; Datt, M.; Visagie, J.L. Carbon coated supports for cobalt based FischerTropsch catalysts. Top. Catal. 2014, in press.

63. Rane, S.; Borg, O.; Yang, J.; Rytter, E.; Holmen, A. Effect of alumina phases on hydrocarbon selectivity in Fischer-Tropsch synthesis. Appl. Catal. A 2010, 388, 160-167.

64. Sietsma, J.R.A.; den Breejen, J.P.; de Jongh, P.E.; van Dillen, J.; Bitter, J.H.; de Jong, K.P. Highly active cobalt-on-silica catalysts for the Fischer-Tropsch synthesis obtained via a novel calcination. Stud. Surf. Sci. Catal. 2007, 167, 85-90.

65. Lu, J.; Elam, J.W.; Stair, P.C. Synthesis and stabilization of supported metal catalysts by atomic layer deposition. Accts. Chem. Res. 2013, 46, 1806-1815.

66. Soled, S.L.; Kiss, G.; Kliewer, C.; Baumgartner, J.; El-Malki, E.-M. Learnings from Co FischerTropsch catalyst studies. Abstracts of Papers, ENFL-412, 245th ACS National Meeting \& Exposition, New Orleans, LA, USA, 7-11 April 2013.

67. Argyle, M.D.; Frost, T.S.; Bartholomew, C.H. Cobalt Fischer Tropsch catalyst deactivation modeled using generalized power law expressions. Top. Catal. 2014, in press.

68. Bakken, V.; Bergene, E.; Rytter, E.; Swang, O. Bimetallic cobalt/rhenium systems: Preferred position of rhenium through an interdisciplinary approach. Catal. Lett. 2010, 135, 21-25. 
69. Tan, K.F.; Xu, J.; Chang, J.; Borgna, A.; Saeys, M. Carbon deposition on Co catalysts during Fischer-Tropsch synthesis: A computational and experimental study. J. Catal. 2010, 274, 121-129.

70. Swart, J.C.W.; Ciobica, I.M.; van Santen, R.A.; van Steen, E. Intermediates in the formation of graphitic carbon on a flat FCC-Co(111) surface. J. Phys. Chem. C 2008, 112, 12899-12904.

71. Burghgraef, $\mathrm{H}$. A quantum chemical study of $\mathrm{CH}$ and $\mathrm{CC}$ bond activation on transition metals. PhD Thesis, Eindhoven University of Technology: Eindhoven, The Netherlands, June 1995.

72. Ciobica, I.M.; van Santen, R.A.; van Berge, P.J.;. van de Loosdrecht, J. Adsorbate induced reconstruction of cobalt surfaces. Surf. Sci. 2008, 602, 17-27.

73. Wilson, J.; de Groot, C. Atomic-scale restructuring in high-pressure catalysis. J. Phys. Chem. 1995, 99, 7860-7866.

74. Schulz, H.; Nie, Z.; Ousmanov, F. Construction of the Fischer-Tropsch regime with cobalt catalysts. Catal. Today 2001, 71, 351-360.

75. Balakrishnan, N.; Joseph, B.; Bhethanabotla, V.R. Effect of Pt and Ru promoters on deactivation of Co catalysts by $\mathrm{C}$ deposition during Fischer-Tropsch synthesis: A DFT study. Appl. Catal. A 2013, 462-463, 107-115.

(C) 2014 by the authors; licensee MDPI, Basel, Switzerland. This article is an open access article distributed under the terms and conditions of the Creative Commons Attribution license (http://creativecommons.org/licenses/by/3.0/). 